Key words: Nitric oxide synthase, Microglia, Astroglia, Transforming growth factor $\beta$, Plasminogen activators, Neurodegeneration

\section{Production, regulation and role of nitric oxide in glial cells}

\author{
V. A. M. Vincent, F. J. H. Tilders and \\ A-M. Van Dam ${ }^{\text {CA }}$
}

Research Institute Neurosciences Free University, Medical Faculty, Department of Pharmacology, Amsterdam, The Netherlands

\author{
${ }^{\mathrm{CA}}$ Corresponding Author \\ Tel: (+31) 204448095 \\ Email: AMW.van_Dam.pharm@med.vu.ul
}

\section{Introduction}

The central nervous system (CNS) consists of two major cell types, neurones and glial cells. Neuronal communication with other neurones or glial cells is effected mainly through neuro-transmitters and peptides, while glial cells appear to use an abundant range of factors for the communication with either neurones or other glial cells. The communication between neurones can span large distances in the body, while glial cell communication is mainly local or paracrine. During the past decade it has become clear that the glial cells named after glue (= glia) have more functions besides acting as a "nerve-glue" to form the brain. ${ }^{1,2}$ The glial cells appeared to be essential for neuronal protection, survival and outgrow th during development and for the neuronal degeneration and regeneration under pathological conditions. In this review we summarize glial cell functions and focus on the role, production and regulation of nitric oxide (NO), a molecule which has been shown to be involved in various neuroimmune processes.

\section{Glial Cells}

Glial cells can be divided into microglial cells and macroglial cells, the latter of which are subdivided in astroglial cells and oligodendrocytes. The oligodendrocytes are known for their myelin production that wraps the axons in the white matter of the brain, and are affected in diseases like multiple sclerosis (MS). Glial cell activation has been indicated in many neuropathological diseases like Alzheimer's disease, ${ }^{3-7}$ Parkinson's disease, ${ }^{5}$ multiple sclerosis, ${ }^{8}$ acquired immune deficiency syndrome (AIDS) dementia complex (ADC $)^{9-11}$ and other disorders.

\section{Microglial cells}

Microglial cells, formerly named Hortegaglia or Mesoglia, have been described in detail for the first time in 1932 by Del Rio-Hortega ${ }^{12}$ considered as the father of mic roglia. Mic roglial cells are ubiquitously distributed in the CNS, show heterogeneous morphology and comprise up to $20 \%$ of the total glial cell population in the brain. ${ }^{13}$ It was Del Rio-Hortega who proposed that microglial cells occur in two morphologically distinct forms, the ameboid or macrophage-like form representing as active microglial cells seen in developing brain and at sites of injury. These cells convert into the highly branched ramified microglial cells ${ }^{14-17}$ viewed as quiescent cells in the mature $\mathrm{CNS}^{18}$ which eventually can transform into active macrophages (reactive microglial cells) (Fig. 1). ${ }^{19,20}$ Del Rio-Hortega suggested that microglial cells served as macrophages or phagocytic cells, which has found substantial support. $^{21-23}$

The name mesoglia was derived from their proposed mesodermal origin. Indeed more recent and elaborative studies support a bone-marrow origin ${ }^{17,24}$ from the usual macrophage precursor. Blood monocytes or monocyte precursors invade the brain during development. ${ }^{25,26}$ In studies using chimeric rats, support was found for the bone marrow origin hypothesis ${ }^{27,28}$ but in other rat chimera experiments the contrary was found. ${ }^{29,30}$ The prevailing concept is however that blood monocytes are the precursors of ameboid microglial cells. There is apparently no need 


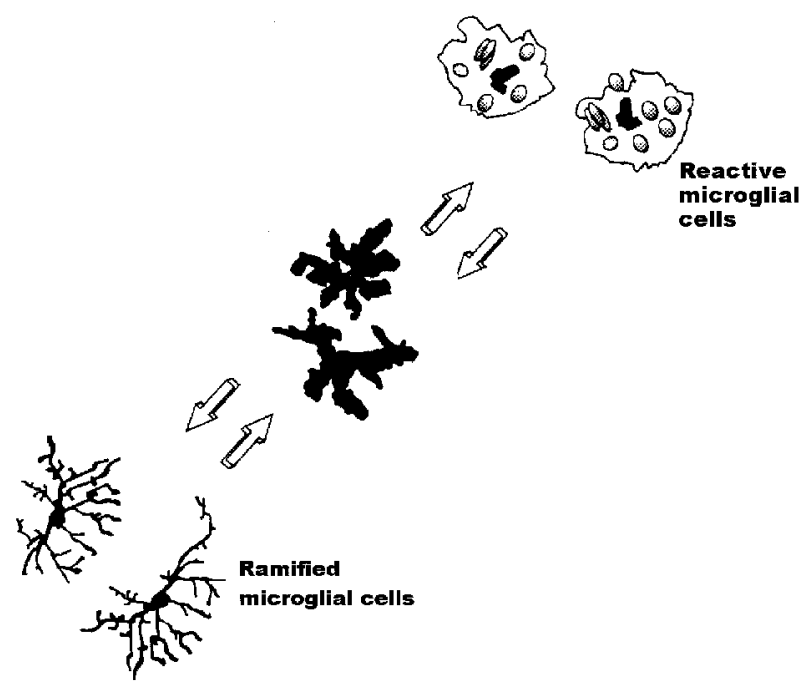

FIG. 1. Microglial cell activation cascade. Schematic drawing illustrating the transition of microglial cells from ramified microglial cells to the ameboid microglial cell, adapted from Ref. 371 .

for the influx of a large number of monocytes into the brain parenchyma under normal conditions, since microglial cells have an extreme long life and have a low turnover rate. ${ }^{31,32}$ Their numbers can be augmented by local proliferation ${ }^{19,33-36}$ or by immigration of blood monocytes. ${ }^{37}$ Under pathological conditions increased monocyte infiltration into the brain parenchyma is found ${ }^{8,38,39}$ and the influx is suggested to be mediated by the microglial cell derived chemokine MCP- $1^{40}$ or adhesion molecules.

\section{Microglial cell functions}

The microglial cells serve as immunoregulatory cells, and are essential for resistance to inter- and intracellular pathogens. The microglial cells are present in a resting or a ramified form (Fig. 2) and are very important in immunosurveillance. After activation of the resting cells the microglial cells exhibit a highly potent phagocytic activity of foreign organisms and material, phagocytosis of injured or necrotic tissue, antimicrobial immunity, elimination of tumour cells and regulate inflammatory responses. ${ }^{41}$ Microglial cells have been reported to possess Fc receptors, ${ }^{18,42}$ CD4 antige $\mathrm{n}^{43}$ and major his tocompatibility complex (MHC) class I and II antigens ${ }^{41,44-46}$ and thus are antigen presentating cells. Interferon- $\gamma$ and interleukin-4 (IL-4) up-regulate MHC class II expression and induce microglial cell proliferation. ${ }^{47}$ In addition, microglial cells show chemotaxic activity, like monocytes and macrophages, to several immunological factors such as complement factor C5a and to transforming grow th factor $\beta$ (TGF $\beta$ ) suggesting that these cells can move to sites of injury and thereby participate in an inflammatory response. ${ }^{12,42,48,49}$ These observations have led to a redefinition of the brain as immune privileged site a concept based on lack of inflammatory responses through the absence of T and B cells.

Microglial cells share many functional characteristics $\mathrm{w}$ ith cells of the monocytic lineage. Interleukin-1 (IL)-1 production by microglial cells has been demonstrated for the first time by Giulian, ${ }^{50}$ and later by many others ${ }^{41,51-54}$ and IL-1 is found to be present in injured brain tissue. ${ }^{50,55}$ Other cytokines produced by microglial cells are TNF- $\alpha,{ }^{54,56,57} \mathrm{IL}-6^{57-59}$ and TGF $\beta^{60-62}$ and they produce prostanoids such as prostaglandin $\mathrm{E}_{2}$, $\left(\mathrm{PGE}_{2}\right), \mathrm{PGD}_{2}$, thromboxane $\mathrm{e}^{63,64}$ and leukotrienes, LTB $_{4}$, LTC $_{4}$ and 5-HETE. ${ }^{65}$ IL-5 was found to be produced by microglial cells in vitro which may be involved in the interaction between glial cells and immune cells in the brain. ${ }^{66}$ IL-10 and TGF $\beta$ both immunosuppressive and anti-inflammatory cytokines, have been demonstrated to be produced by human microglial cells and down-regulate microglial cell functions. ${ }^{60,67-71}$ These properties confirm that microglial cells can initiate and regulate immune and inflammatory responses within the brain.

\section{Astroglial cells}

Astrocytes, oligodendrocytes and neurons are of ectodermal origin, and derive from the neuroepitelium of the primitive neural tube. Astroglial cells, unlike neurones, retain the ability to divide throughout life. ${ }^{72}$ The multipotential stem cell develops into the bipotential progenitor cell and finally the glial lineage-restricted progenitor cell which can differentiate into the oligodendrocyte, the astrocyte type 1 and type $2 .^{73-76}$ The astrocytes outnumber neurones 10:1 in mammalian brain, and as their name imply, they have a star-shaped morphology. The astrocytes can be identified by using specific markers such as glial fibrillary acidic protein (GFAP), and glutamine synthase (GS), that are specific for both types of astroglial cells. ${ }^{77-81}$

Each cell forms processes that contact the blood vessels, where they form the so-called end-feet or sucker processes which also forms part of the bloodbrain barrier (BBB) together with endothelial cells and the lamina basalis. ${ }^{72}$ Astrocytes in the white matter are referred to as fibrous astrocytes, with numerous fibrils within their cytoplasm. In the grey matter, the astrocytes generally contain few fibrils and are called protoplasmic astrocytes. Interestingly, in vitro also two types of astrocytes can be identified, type 1 and type 2 astrocytes which are thought to be in vitro analogous of the protoplasmic and fibrous astrocytes respectively $^{82}$ (Fig. 2).

\section{Astroglial cell functions}

Initially the function of astroglial cells was thought to be a structural support within the CNS, with their processes having junctions with other astroglial cells, endothelial cells and neurones. In addi- 

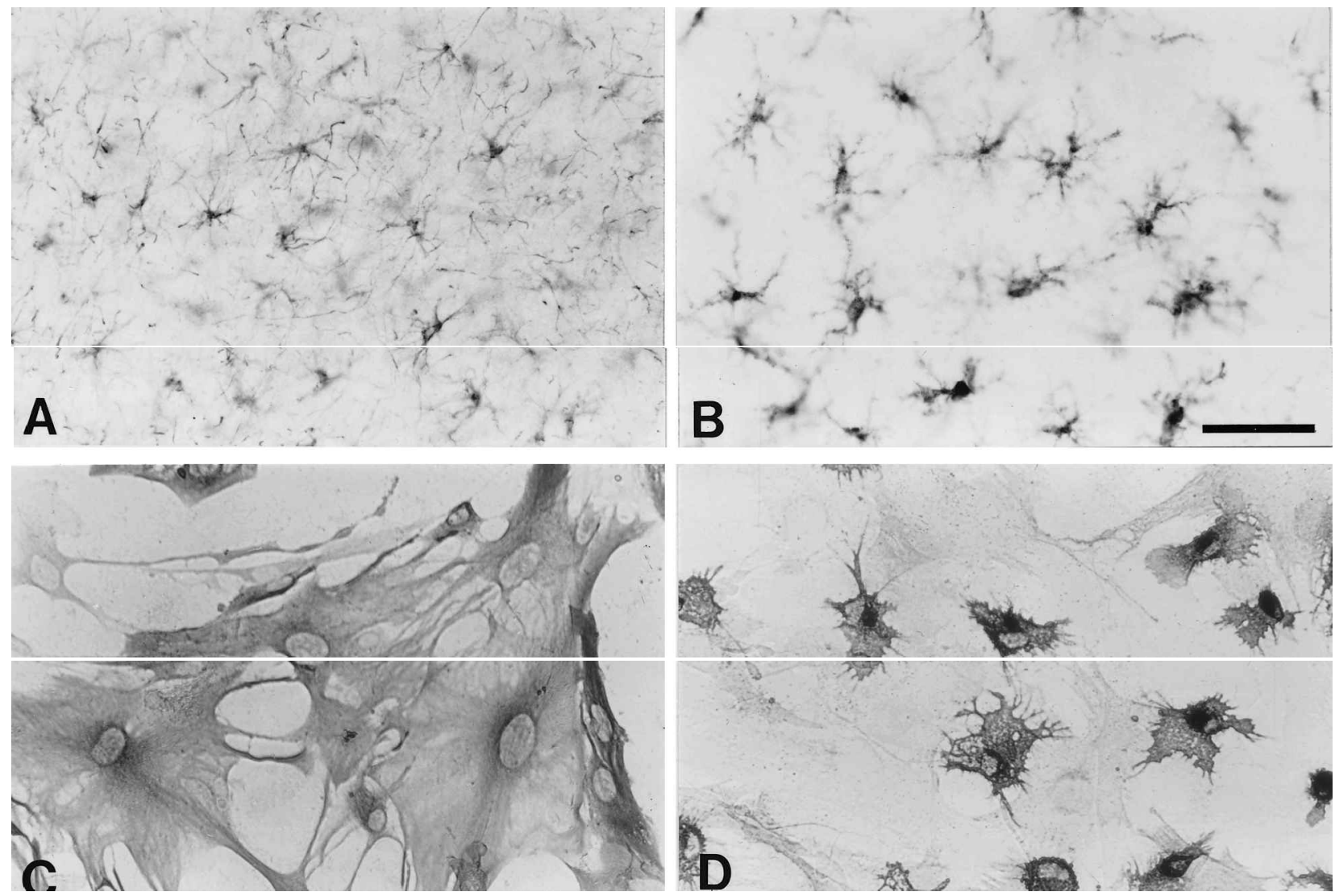

FIG. 2. Microglial cells and astroglial cells in rat brain in vivo and in vitro stained for GSA-I-B4-isolectin and GFAP respectively. (A) GFAP staining of astroglial cells in rat brain; (B) GSA-I-B4-isolectin staining ramified microglial cells in a rat brain; (C) GFAP in vitro in a purified astroglial cell culture; (D) GSA-I-B4-isolectin in vitro in a purified ameboid microglial cell culture. A, B, bar $=66 \mathrm{~mm} ; \mathrm{C}, \mathrm{D}$, bar $=25 \mathrm{~mm}$.

tion in repair mechanisms the astroglial cells fill open spaces by proliferating and thereby forming a glial scar. ${ }^{83-86}$

It is now known that astroglial cells are very important cells in the outgrowth and survival of ne urones during development and in neuropathology. Astroglial cells produce nerve grow th factor (NGF) ${ }^{87}$ in vitro and in vivo and the production of NGF is increased by IL- $1,{ }^{88-92}$ TNFo, ${ }^{93}$ IL 4 and IL- $5 .{ }^{94}$ Other ne urotrophic factors produced by astroglial cells are ciliary neurotrophic factor (CNTF), brain-derived neurotrophic factors (BDNF) and fibroblast grow th factor (FGF). ${ }^{95,96}$

Astrocytes produce cytokines like IL-1, ${ }^{41,97-100}$ IL$6,{ }^{101}$ IL-3, ${ }^{102}$ TGF $\beta^{60,62,103-105}$ and IL-15 ${ }^{106}$ and factors like prostaglandin $\mathrm{E}_{2}\left(\mathrm{PGE}_{2}\right),{ }^{97,99,107,108}$ granulocytemacrophage colony-stimulating factor (GM$\mathrm{CSF})^{109,110}$ and microglial mitogens (MM). ${ }^{111} \mathrm{TNF} \alpha$ is also produced by astroglial cells in vitro after lipopolysaccharide (components of Gram-negative bacterial outer membranes; LPS) ${ }^{56,112}$ and IL-1 $\beta$ stimulation $^{59,106}$ or mycoplasma infection. ${ }^{108}$

Astrocytes can be induced to express MHC I and II class molecules in vitro and are able to present antige $n^{113,114}$ and thus are important immune cells in the brain. However, in contrast to microglial cells they do not express significant levels of MHC class II molecules ${ }^{115}$ in vivo.

\section{Glia-glia interactions}

Recent studies have shown various interactions between microglial cells and astroglial cells. IL-1 produced by microglial cells has been shown to stimulate astroglial cell proliferation in vitro. ${ }^{116-119}$ Intracerebral injections of IL-1 or local production of IL-1 by microglial cells elicit astrogliosis which may result in scar formation ${ }^{120,121}$ and thereby have a negative effect on axonal outgrow th and remyelination. In addition the microglial cells influence the production of NGF by astroglial cells, which is enhanced after IL-1 and IL-5 both produced by microglial cells. ${ }^{66,94,122}$

On the other hand, astroglial cells influence microglial cell functions. Interleukin-3 (IL-3) is mitogenic to microglial cells and has been suggested to be produced by astrocytes. ${ }^{102,123}$ Mitotic activity of microglial cells can additionally be elevated by colony stimulating factor-1 (CSF-1), which production is increased by IL-1, TNFo, ${ }^{124}$ granulocyte-macrophage 
colony-stimulating factor (GM-CSF) $41,109,110,122,125-127$ or microglial mitogen (MM). ${ }^{11}$

The microglial cells undergo morphological changes in response to factors released by or through cellcell contact with astrocytes. These factors derived from astrocytes, induce microglial cells to become the ramified, functionally resting cells in vitro, while inflammatory mediators like interferon $\gamma$ (IFN $\gamma$ ) and LPS induce microglial cells to become ameboid. ${ }^{128,129}$ Also, blood monocytes and spleen macrophages differentiate into ramified microglial cells when cultured onto an astroglial cell monolayer. ${ }^{130,131}$ This illustrates the capacity of astroglial cells to transform cells from monocytic origin into cells with microglial cell morphology.

In addition, astroglial cells have been shown to functionally regulate microglial cell activity. The endotoxin induced synthesis of iNOS and release of NO but not the production of IL-1 $\beta$ by microglial cells is inhibited in the presence of astroglial cells in vitro. ${ }^{51}$

Apparently both glial cells communicate through the production of various factors including cytokines and grow th factors. In this way the glial cells appear to tightly regulate each others morphology, activity and secretion of products.

\section{Glia-neurone interactions}

The presence of glia-derived cytokines in the CNS and the function of these cytokines in vitro suggest that they are important for normal brain development and homeostasis. ${ }^{132,133}$ However, excessive expression of these cytokines may be a factor in abnormal glial functions leading to neuropathological events.

In general astrocytes have been found to express neurotrophic factors such as ciliary neurotrophic factor (CNTF), ne urotrophin-3, fibroblast grow th factor (FGF) and NGF near the site of injury. ${ }^{134,135}$ In vitro experiments show that astrocytes protect dopaminergic neurons against $\mathrm{H}_{2} \mathrm{O}_{2}$ toxicity ${ }^{136}$ through actions of glutatione. Interestingly, survival of these dopaminergic neurones in vitro is enhanced by the presence of glial cells derived from striatal astroglia: the target-derived astroglial cells, illustrating astroglial cell he terogeneity. ${ }^{137,138}$ The survival of dopaminergic neurones is promoted by glial cell-lined derived ne urotrophic factor (GDNF) in vivo. ${ }^{139}$ In vitro cocultures of neurones and astrocytes induced an increased cell survival and neurite outgrow th ${ }^{140-142}$ and axons might trigger glial differentiation. ${ }^{143}$ The ability of astrocytes to augment ne uronal survival was increased after treatment of the astrocytes with macrophage conditioned medium ${ }^{144}$ indicating that factors produced by macrophages induce the production of ne urotrophic factors.

Neurones are less sensitive to oxygen or glucose deprivation or treatment with glutamate when co- cultured with astrocytes. ${ }^{145}$ In addition astrocytes increase neuronal survival under pathological conditions since they have an energy reserve stored as glycogen which becomes available for neurones under conditions of energy substrate limitations. ${ }^{146}$ Astroglial cells are important in the metabolism of glutamate and GABA and other neurotransmitters, ${ }^{147}$ and maintain the microenvironment by regulating the ionic composition of the extracellular space around the neurones. ${ }^{148}$

Neurotrophic effects i.e. neuronal survival and neurite extension have also been reported by microglial cell conditioned medium ${ }^{149}$ and more specifically by the production of $\mathrm{NGF}^{150}$ and thrombospondin. ${ }^{151,152}$ In addition secre tion of IL-6, IL-1, FGF, TGF $\beta$, TNF $\alpha$ by microglial cells and astroglial cells may stimulate nerve growth factor production by astroglial cells for the regeneration of neurones. ${ }^{93,134,153-158}$ These factors also directly improve the survival of neurones and/or have synergistic effects with NGF ${ }^{159,160}$

While in general factors released by astroglial cells actually increase the survival of neurones, ${ }^{161}$ microglial cells in contrast, can directly participate in neuronal cell death through the release of neurotoxins. ${ }^{162}$ Microglial cells have been reported in the presence of degenerating neurones in various regions in the brain. ${ }^{18,163-165}$ In these regions the microglial cells clearly contribute to the removal of pycnotic cell bodies. Prior to this scavenger role, the active participation of microglial cells in neurite amputation has been shown on electron microscopic pictures of microglial cells engulfing axon processes which display no obvious signs of degeneration. ${ }^{166}$ It is therefore thought that interactions between neurones and microglial cells may not be restricted to cell debris scavenging but microglial cells may also induce ne uronal cell death.

In vitro studies have demonstrated the production of many different neurotoxins by microglial cells. Activated microglial cells release several cytotoxic compounds i.e. reactive oxygen intermediates, ${ }^{167,168}$ NO, proteases s $^{51,169-172}$ and inflammatory cytokines i.e. IL-1, TNF $\gamma$ or TNFa, ${ }^{50,56,119,127,157,173,174}$ that play a role in neuronal damage in the CNS. Finally microglial cells produce large amounts of glutamate and aspartate in vitro. ${ }^{175}$ The release of these excitatory amino acids points to a further role of microglial cells in NMDA receptor-mediated neuronal injury. ${ }^{175}$ In addition, cultured microglial cell rele ase large amounts of $\mathrm{H}_{2} \mathrm{O}_{2}$, which leads to neuronal cell death in neuronemicroglial cell cocultures. ${ }^{172,176,177}$

Taken together, activated microglial cells display a broad repertoire of cytotoxic functions which could be involved in tissue damage during CNS injury. In addition, microglial cells activate astroglial cells in a way that benefits regeneration. Further, the effect of neurotoxic factors released by microglial cells can be 
attenuated by proteins released from astroglial cells. ${ }^{178,179}$ This illustrates the fascinating and delicate interactions that exist between glial cells and neurones, which are crucial in maintaining neural functioning and integrity. These studies have contributed towards a concept which considers reactive microglial cells as an opposing force to neurotrophic astroglia, the two glial cell populations rivaling in regulating survival of neurones. ${ }^{180}$

\section{Nitric Oxide in the CNS}

Various cell types in the CNS, i.e. neurones, endothelial cells, microglial cells and astroglial cells produce NO. Different is oforms of the nitric oxide synthase (NOS) are responsible for the production of $\mathrm{NO}$ by these cell types. NO in the brain is multipotent and is responsible for blood flow regulation, may act as a neurotransmitter or as a neurotoxic agent, depending on the cellular source, amount and production site.

\section{Isoforms of nitric oxide synthase}

NO, a free radical gas, was found to be responsible for the vasodilatation in arteries and at first named endothelium derived relaxing factor (EDRF). ${ }^{181}$ Later the source of $\mathrm{NO}$ was elucidated revealing the enzymatically conversion of L-arginine to L-citrulline by NO synthase whereby NO is produced (Fig. 3). ${ }^{182}$ Three isoforms of NOS, encoded by different genes $^{183}$ have been characterized, isolated and cloned to further study the physiologic and/or pathologic functions of NO. ${ }^{184}$ All three isoforms, endothelial (eNOS, ecNOS or type III), constitutive (cNOS, nNOS, bNOS or type 1) found in astroglial cells and neurones and inducible (iNOS, mNOS, macNOS or type II), NOS are found in the CNS and play a role in certain physiological or pathological functions of the CNS (see following section). ${ }^{185}$ Constitutive NOS is constitutively expressed in neurones, is $\mathrm{Ca}^{2+}$ and calmodulin dependent, and mediates the production of only small amounts of $\mathrm{NO}$ after stimulation. This neuron derived $\mathrm{NO}$ is very rapidly produced and released since cNOS is constitutively expressed and does not require mRNA synthesis, acts as a neurotransmitter with properties that differ from other neurotransmitters: (a) it is not stored in vesicles, (b) there are no specific release or uptake mechanisms and (c) its transmission is not synaptic. NO diffuses into the target cell and directly regulates enzymes systems, such as activation of guanylate cyclase, resulting in increased cGMP levels. ${ }^{186,187} \mathrm{NO}$ has a half life of a few seconds in contrast to the milliseconds of the neurotransmitters in classical synapses. ${ }^{188,189}$ It is important in neurotransmission, and $\mathrm{NO}$ is considered a candidate for a memory-related process named long-term-potentiation (LTP). ${ }^{190,191}$ Indeed, inhibitors of NOS can

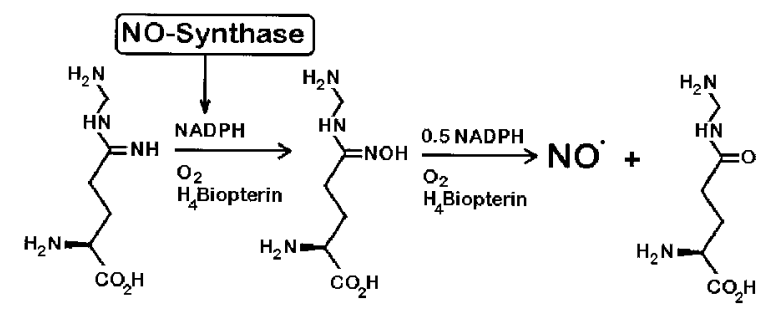

L-arginine L-Ng-OH-arginine

L-citrulline

FIG. 3. Biosynthesis of NO through the so-called L-arginineNO pathway, adapted from Ref. 372.

block LTP. ${ }^{192,193}$ In areas such as the cerebral cortex, hippocampus, cerebellum and corpus striatum, cNOS expressing neurones compose $1-2 \%$ of all neuronal cells. ${ }^{194}$ Activation of cNOS in astroglial cells was observed after challenge with calcium ionophores, bradykinin or glutamate. ${ }^{185}$

Endothelial NOS (eNOS) produced by endothelial cells is a constitutive $\mathrm{Ca}^{2+}$-dependent enzyme that is essential for the control of vascular tone. NO transduces a signal from the endothelial cell to the vascular smooth muscle eventually leading to cGMP production and vasodilation. In the brain, eNOS-derived NO regulates cerebrovascular blood flow. ${ }^{195}$

Inducible NOS (iNOS) is a $\mathrm{Ca}^{2+}$ and calmodulin independent enzyme. It requires gene transcription, is slowly produced and is activated only under pathological situations where microglial cells and macrophages exert cytotoxic effects in response to cytokines. ${ }^{196}$ The generation of NO by iNOS is longlasting, in contrast to the cNOS and eNOS is oforms where NO is generated in short bursts. ${ }^{197,198}$ The mechanism of iNOS induction involves transcription of mRNA and novel protein synthesis and it takes several hours before $\mathrm{NO}$ is generated after the initiating signal. ${ }^{199}$ It induces a 100 -fold higher local concentrations of NO than eNOS or cNOS and act as a antimicrobial defence mechanism of the immune system. iNOS is not expressed in normal brains but expression can be induced in astroglial and microglial cells through viral infection or trauma. ${ }^{200,201}$ It is mainly expressed under inflammatory conditions, and after transient ischaemic periods. ${ }^{202-205}$

\section{Nitric oxide in neuropathology}

NO can be neurotoxic under different circumstances. The NO mediated neuronal cell death can be induced by overexpression of cNOS in ne urones and astroglial cells or iNOS induction in glial cells, both pathways will be further discussed below (see Fig. 4).

cNOS induced NO mediated neurotoxicity

Glutamate binding to its NMDA receptor induces NO production by cNOS activation. Derangements of 


\section{Nitric Oxide Mediated Neurotoxicity}

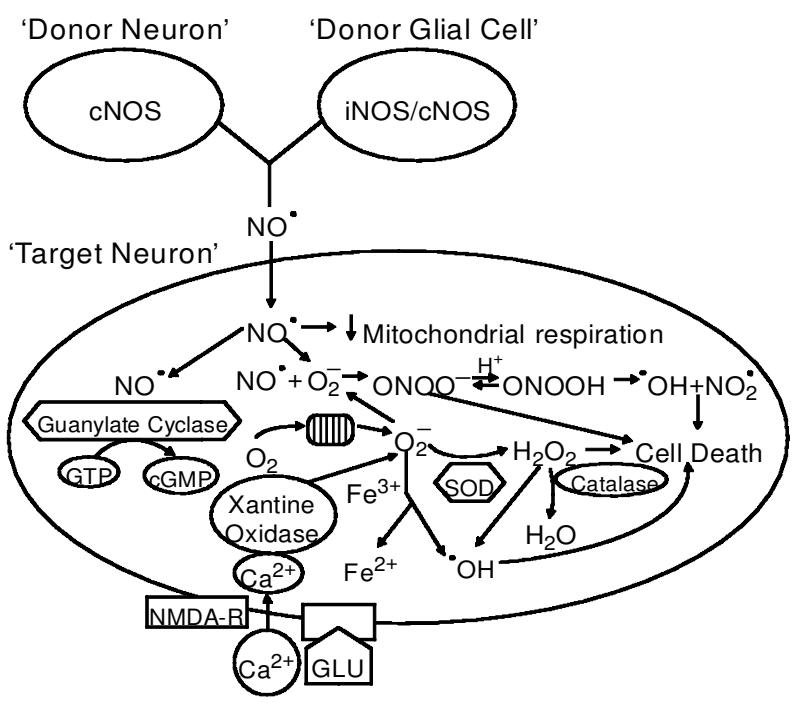

FIG. 4. NO as neurotoxin. Excessive NO is formed on sustained glutamate stimulation of NMDA receptors by cNOS in neurones or by activation of iNOS or cNOS in glial cells. NO freely diffuses to adjacent target neurones where it combines with the $\mathrm{O}_{2}^{-}$to yield the peroxynitrite, ONOO-, which is an extremely potent oxidant. Although $\mathrm{NO}$ can function as a toxin directly, the peroxynitrite pathway may be the major pathway of cell death, adapted from Ref. 303.

glutamate neurotransmission leading to neurotoxicity has been implicated in Alzheimer's disease, Huntington's disease, amyotrophic lateral sclerosis (ALS), epilepsy and stroke. ${ }^{206,207}$ Glumate neurotoxicity is demonstrated to be mediated through NO production. After binding of glutamate with the NMDA subtype of glutamate receptors, $\mathrm{Ca}^{2+}$ enters the channel and binds to calmodulin, a cofactor for cNOS and stimulates NOS activity whereby $\mathrm{NO}$ is produced. $^{208}$ In addition, $\mathrm{O}_{2}^{-}$is produced which results in the formation of $\mathrm{ONOO}^{-}$which subsequently leads to neuronal death..$^{209-211}$ Neurones obtained from cNOS null transgenic mice are markedly resistant to ischaemic conditions, ${ }^{212}$ in which the primary mechanism of damage is mediated by activation of the NMDA receptor and subsequent formation of NO. This indicates that cNOS is capable of producing neurotoxic amounts of NO. ${ }^{213}$

\section{iNOS induced NO mediated neurotoxicity}

The iNOS-mediated release of NO by astrocytes and microglial cells in the brain may be important in antimicrobial or tumoricidal responses to inflammatory signals. ${ }^{197}$ In acute CNS inflammatory conditions like rabies, herpes simplex, Borna, and lymphocytic choriomeningitis virus, iNOS is expressed $\mathrm{d}^{200,214-217}$ as well as in experimental pneumococcal meningitis and toxoplasmosis and in humans during encephalitis. ${ }^{130,218-220}$ iNOS mediated $\mathrm{NO}$ is considered to mediate neuronal and oligodendrocyte degeneration under neuropathological conditions. ${ }^{202,221,222}$ The role of iNOS in neuropathology in general is indirect, microglial cells and/or macrophages become activated either through direct infection with virus or other pathogens, or by local cytokine production and subsequently produce iNOS which eventually leads to damage. Excessive amounts of NO produced by glial cell are probably neurotoxic. iNOS-derived $\mathrm{NO}$ is one of the major sources of toxic free radicals in the brain, since its reaction $w$ ith the superoxide anion $\left(\mathrm{O}_{2}^{-}\right)$ leads to the formation of peroxynitrite anion $\left(\mathrm{ONOO}^{-}\right)$which is an extremely potent oxidizing agent. $^{223}$ Peroxynitrite generates DNA-single-strand breaks with subsequent activation of the DNA repair enzyme poly ADP ribosyltransferase (PARS). ${ }^{224}$ Furthermore, NO and peroxynitrite have been show $n$ to inhibit the mitochondrial respiratory chain and disrupt normal cellular iron homeostasis. ${ }^{201,225-227} \mathrm{Per}$ oxynitrite and/or NO can terminally damage neurones, leading to cell death. ${ }^{22-232}$ Low levels of or sustained exposure to NO or peroxynitrite cause apoptosis, whereas sudden exposure to high concentrations of NO or peroxynitrite leads to necrosis. ${ }^{233}$

\section{$N O$ in Alzheimer's disease and MS}

iNOS expression is found in Alzheimer's disease $e^{234,235}$ and in experimentally infected brains of rats with various viral agents. ${ }^{200} \mathrm{NO}$ has been implicated in demyelination and destruction of oligodendrocytes and subsequent demyelination, the process found in $\mathrm{MS}^{236}$ and in the primary animal model for MS, experimental allergic encephalomyelitis (EAE)..$^{216,237}$ During EAE, iNOS mRNA is detectable before the onset of the clinical symptoms and the levels of protein correlate with the severity of the disease. ${ }^{200}$ Further evidence supporting a role for iNOS in the pathogenesis of MS is the finding that human iNOS protein and mRNA is markedly elevated in the active lesions in brains of MS patients. ${ }^{238,239}$ In MS lesions, macrophages appear to produce iNOS and are NADPH-diaphorase positive after his tochemical staining. ${ }^{240}$ In another study, NADPH-diaphorase activity in MS lesions was found in reactive astroglial cells ${ }^{239}$ which was later shown to be cNOS. ${ }^{240}$ The cellular source of iNOS mRNA expression in brains of patients with MS has been confirmed to be macrophages/ microglial cells. ${ }^{238}$ In EAE an increase was found in eNOS in blood vessels in the inflamed lesions and increase in iNOS in infiltrating inflammatory cells. ${ }^{216,241}$ iNOS expression can be (further) induced by cytokines like TNF $\alpha$, IFN $\gamma$ and IL-1, that are all detected in brains of MS patients. ${ }^{242-245}$

\section{NO in AIDS dementia complex}

iNOS-mediated NO production has also been described to be involved in acquired immune deficiency syndrome (AIDS)-related neuropathology. iNOS prote in and mRNA was found in the CNS of patients with AIDS dementia complex (ADC),,$^{246,247}$ and is 
expressed at higher levels than in brains of AIDS patients without neurological symptoms. The cell types expressing iNOS however, remain unknown. In these patients there is a clear correlation between the severity of the dementia and iNOS expression in the brain. In addition in brain tissue of simian immunodeficiency virus (SIV) infected monkeys iNOS mRNA was detected. ${ }^{248}$ The microglial cells have been postulated to be involved in the pathogenesis of ADC because they are preferentially infected by the virus. ${ }^{43,249-251}$ Neuropathological manifestations such as loss of cortical neurones, loss of synapses and ne uronal apoptosis have therefore been suggested to be mediated indirectly by cytokines like TNFa ${ }^{252,253}$ and IL-1 ${ }^{254-256}$ or by nitric oxide. ${ }^{257-261}$ TNFo, IL-1 and iNOS have been demonstrated in brains of AIDS patients ${ }^{247,256,262-265}$ as well as in ADC patients ${ }^{259,266,267}$ (Vincent $e$ t al., submitted). In cytomegalovirus (CMV) infected retinas from AIDS patients iNOS immunoreactivity and NADPH-diaphorase were found in (CMV)-infected cells identified as Müller cells and astrocytes. ${ }^{268}$

\section{$N O$ in parkinson's disease}

In Parkinson's disease, which is primarily characterized by a loss of midbrain dopaminergic neurones, iNOS was present in glial cells ${ }^{269}$ in the mesecephalon probably in activated macrophages. ${ }^{269}$ In addition, NOS inhibitors attenuate malonate-induced degeneration by NMDA receptor activation of the nigrostriatal pathway in rats ${ }^{270}$ suggesting a role for $\mathrm{NO}$ in ne urodegeneration. The inhibition of tyrosine hydrox ylase resulting in reduced dopamine synthesis is triggered by peroxynitrite, a reaction product of NO.

\section{NO in brain activation}

During ischaemic brain damage eNOS is induced in endothelial cells which then has beneficial effects by enhancing the vasodilation, further increasing blood flow in the peri-infarct area. ${ }^{272,273}$ In addition iNOS is induced leading to NO production, which leads to neuronal death after cerebral ischaemia. ${ }^{274}$ During postnatal brain development of rats, large numbers of NADPH-diaphorase positive neurones and NADPHdiaphorase positive cells with macrophage morphology were observed. The latter are possibly involved in developmental shaping of the brain, which includes cell death and fagocytosis of cellular debris. ${ }^{275} \mathrm{High}$ levels of NADPH-diaphorase were found in evenly distributed astroglial cells in areas surrounding a mechanical lesion in the brain. Within the lesion the NADPH-diaphorase positive cells most probably were macrophages. ${ }^{276}$

Thus, although iNOS and NADPH-diaphorase activity can be induced in astrocytes and microglial cells through viral infection or trauma most of the studies have revealed iNOS immunoreactivity and iNOS
mRNA in the brain in infiltrating macrophages or microglial cells. ${ }^{210}$ In general, exposure of brain cells to signals, such as microbial products, viruses, glutamate or yet unknown signals in diseases like MS, Alzheimer's and Parkinson's disease leads to the secretion of inflammatory cytokines that induce either de novo synthesis of iNOS by glial cells or cNOS in astroglial cells or neurons as has been demonstrated in in vitro studies. This NO may be neurotoxic and may subsequently lead to ne uropathology.

\section{Production of iNOS in vitro}

To answer some more fundamental questions regarding iNOS production and regulation in vitro studies are widely used. Sources, induction mechanism and intervention of iNOS production are studied in detail in various glial cell cultures. In addition, a model has been developed that allows studies of the possible neurotoxic effects of glial NO, on cultured neurons. These in vitro studies have led to new insights in the functions of glial cells in normal brain and in ne uropathology.

Several techniques have been described for isolation of rat murine or human brain microglial cells, astroglial cells and maintenance of these cells in vitro. ${ }^{118,240,277-282}$ The microglial cells and astroglial cells are isolated from mixed glial cultures in most instances or from disrupted adult or neonatal tissue. ${ }^{53,127,171,279,283-285}$ In tissue culture, the ameboid and ramified microglial cell can be identified, most probably corresponding to its morphological diversity in the adult brain. ${ }^{286}$ The astroglial cell cultures can be contaminated with microglial cells, since the purification of astroglial cells is a rather delicate technique and microglial cells remain a significant contaminant. ${ }^{56,161,287}$ Many studies showing production of, for example, cytokines like IL-1 or TNF $\alpha$ by astroglial cells in vitro have to be interpreted with care. In vitro studies also provide a very useful technique to study both the functions of glial cells and of neurones as well as the interactions between these cell types. Therefore techniques for selective isolation, co-culturing, labeling and stimulation of microglial cells and astroglial cells allow investigators to study some fundamental questions in neuro-immunology.

\section{Glial cell-derived iNOS}

iNOS expression by glial cells has been studied in in vitro systems of highly purified microglial cell and astroglial cell cultures and in mixed cultures containing both cell types from human or rodent brain. Following incubations with various stimuli, both mic roglial and astroglial cells have been demonstrated to produce nitrate, one of the end-products of nitric oxide oxidation. ${ }^{203}$ 
iNOS has been identified in rodent astrocytes and microglial cells in response to IL-1 $\beta$, LPS or Grampositive bacterial products. ${ }^{185,259,288,289}$ IFN $\gamma$ induces $\mathrm{NO}$ in microglial cells and macrophages but not in astroglial cells, ${ }^{203,221,290-292}$ while synergism of IFN $\gamma$ and IL-1 $\beta$ or TNF $\alpha$ induce significant levels of nitrite in rodent and human astroglial cells. ${ }^{203,239,250,293,294}$ LPS induction of iNOS required CD14 expression on glial cells. ${ }^{295}$ As yet it is not clear whether cytokines activate gene expression via one or multiple pathways. Experiments with phorbol esters, which induce iNOS, suggest that protein kinase $\mathrm{C}$ may be involved in the induction process in microglial cells and astrocytes. $^{296}$

Agents like IFN $\gamma$ and LPS are more effective inducers of iNOS in rodent than in human microglial cells, ${ }^{198,250,288,297}$ which therefore appears to be species-dependent as described for NO production by retinal pigment epithelial cells. ${ }^{298}$ Recently, some studies did however reveal NO and iNOS mRNA production in human ramified microglial cells upon LPS or TNFa stimulation. ${ }^{267,299}$

HIV or the HIV type I coat proteins gp 120 or gp 41 induce iNOS in cultured microglial cells, monocytes or macrophages. ${ }^{9,246,257,258,266}$ In human fetal glial cells, comparable amounts of $\mathrm{NO}$ were induced by gp 120, gp 41 and the proinflammatory cytokines IFN $\gamma$ and IL-1 $\beta$.' HIV-infected brain mononuclear macrophage secrete $\mathrm{NO}$ and $\mathrm{O}_{2}^{-},{ }^{266}$ especially after immune activation and TNF $\alpha$ further increases NO production. In MS and EAE, macrophages isolated from lesion areas produced significant amounts of nitrite and were shown to be iNOS positive without any further stimulation. $^{240,300}$

$\beta$-amyloid, the major component of the senile plaques in Alzheimer's disease, causes a significant increase in NO by microglial cells and not in astroglial cells. The NO production induced by the $\beta$-amyloid was increased by IFN $\gamma^{301,302}$ or phorbol-myristateacetate (PMA) challenge. ${ }^{168}$

Studies that have attempted to compare rat microglial cell and astrocyte NO production have concluded that microglial cells produce more $\mathrm{NO}$ on a per cell basis than astrocytes. ${ }^{202,222,290}$ This has led to the suggestion that activated microglial cells rather than astrocytes are the principal source of reactive nitrogen intermediates in the CNS, and that the NO produced by astroglial cells might be beneficial, whereas microglial-derived NO might be involved in ne urotoxicity. ${ }^{185}$

\section{Nitric oxide mediated neurotoxicity in vitro}

In vitro co-cultures of glial cells with neurones have proven to be a valuable tool in the identification of $\mathrm{NO}$ as a neurotoxin and the cellular sources of NO. Exogenous NO generated from NO donors have been show $\mathrm{n}$ to kill neurones in vitro. ${ }^{224}$ Cytokine-activated murine microglial cells and astroglial cells apparently generate substantial amounts of $\mathrm{NO}$ that kill neurones in vitro, ${ }^{202,222,259,288,303,304}$ since inhibition of endogenously formed NO by specific NOS inhibitors blocks this microglia-or as trocyte-mediated ne urotoxicity. $^{202,260,305}$ For example, factors like LPS, gp41 and $\beta$-amyloid can indirectly kill neurones in mixed cultures with glial cells, which is abrogated by NOSinhibitors. ${ }^{246,301}$ LPS or cytokine activated glial cells stimulate the production of neurotoxins, e.g. NO, because LPS and cytokines do not directly influence the viability of purified neurones. ${ }^{307}$ These studies clearly illustrate the indirect mechanism by which neurones are thought to be killed. ${ }^{306}$

The glial cells produce large amounts of NO by iNOS activity which can form peroxynitrite which is toxic to neurones as previously described. In addition, glutamate neurotoxicity is also mediated by NO in primary neuronal cultures. ${ }^{303}$ Peroxynitrite, NO and NMDA can damage neurones in vitro leading to necrotic or apoptotic cell death pending on the concentration and duration of the exposure. ${ }^{29}$ In addition, oligodendrocytes are also being killed by an NO dependent mechanism by ameboid microglial cells in vitro, suggesting that iNOS expression by invading and intrinsic brain cells play a role in lesion formation in multiple sclerosis. ${ }^{221}$

Although glial cells produce various neurotoxins i.e. TNF $\alpha$, glutamate and PAF, production of $\mathrm{NO}$ appears to play a key role in different neurotoxic pathways since inhibition of iNOS spares the neurones. ${ }^{260,305,308}$ These in vitro findings suggest an important role for glial iNOS derived $\mathrm{NO}$ in the pathophysiology of CNS diseases.

\section{Regulation of NO Production}

Since NO is shown to play an important role in ne urotoxicity, inhibition of NO could be a possible route of intervention in the prevention of neuropathogenesis. Experimentally often used inhibitors of NOS production are synthetic arginine analogues like $N^{\mathrm{G}}$-mono-methylarginine (NMMA), $\mathrm{Nw}$-nitroL-arginine methyl ester (L-NAME), aminoguanidine and $N^{\mathrm{G}}$-nitroarginine. ${ }^{239,258,309}$ They are often used in in vitro studies to certify the L-arginine dependent origin of $\mathrm{NO}$.

Intervention of NO synthesis in vivo by using NOS specific inhibitors has been described in EAE using different arginine analogues e.g. aminoguanidine, L-NMMA and L-NAME. ${ }^{241,300,310,311}$ In these experiments, the effects of these inhibitors on the clinical score of EAE were not conclusive. The aspecificity of these inhibitors for the subtypes of NOS, and thereby effects on eNOS and cNOS leading to e.g. vascular changes, may explain these different results. The search for pharmacological tools that selectively inhibit iNOS, eNOS or cNOS is currently getting much attention and thus far has yielded some agents. The 
agent 7-nitroindazole is a selective cNOS inhibitor and $N^{\mathrm{G}}$-nitro-L-arginine shows a preference for eNOS and cNOS over iNOS, whereas $L-N^{6}-(1$-iminoethyl)lysine is selective for iNOS over cNOS. ${ }^{312}$

Interestingly, $\mathrm{NO}$ can also act as a negative feedback signal on iNOS activity, by inhibiting the transcriptional induction of NOS, indicating a self-regulatory mechanis m. ${ }^{313,314}$ In cultures of rat astroglial cells norepinephrine and dexamethasone have been shown to suppress iNOS induction. ${ }^{257,288,289,315}$ In addition, prostanoids are involved in the regulation of iNOS since prostaglandin $\mathrm{E}_{2}$ but also cyclooxygenase inhibitors suppress iNOS expression in LPS activated rat microglial cells. ${ }^{316}$ In addition several endogenously produced cytokines have been shown to inhibit NO production. TGF $\beta$, IL 4 and IL-10, are known to inhibit NOS activity in monocytes $^{9,221,266,305,317-320}$ and synergistically suppress NO production. ${ }^{70}$ TGF $\beta$ is an important modulator in the brain during development ${ }^{321}$ and TGF $\beta$ has been demonstrated in brains of HIV patients, around brain tumours, in MS, Alzheimer's disease, brain ischaemia, peripheral nerve transections and in several experimental lesions in animals. ${ }^{322-330}$

\section{Transforming growth factor $\beta$ (TGF $\beta$ )}

TGF $\beta$ is a $25 \mathrm{kDa}$ homodimeric prote in secreted by a variety of cells as a latent protein complex. ${ }^{60}$ There are at least five distinct gene products that constitute the TGF $\beta$ family, TGF $\beta 1$ th rough TGF $\beta 5$ which show a high degree (70-80\%) of amino acid sequence identity. The three highly homologous mammalian TGF $\beta$ is oforms are TGF $\beta 1$, TGF $\beta 2$ and TGF $\beta 3$ with relatively high sequence similarities but differences in receptor binding affinities. ${ }^{331}$ Three different TGF $\beta$ receptors have been identified, type I to type III, which distributions are ubiquitous in various body tissues.

In a variety of studies of microglial cell cultures, TGF $\beta$ has been shown to be a potent immunosuppressive cytokine ${ }^{332}$ and inhibits NO production by microglial cells. ${ }^{333}$ TGF $\beta$ inhibits iNOS expression by decreasing iNOS mRNA stability and inhibiting its translation and increasing iNOS protein degradation, ${ }^{334}$ resulting in reduced $\mathrm{NO}$ production. ${ }^{317,335}$ Not only $\mathrm{NO}$ but also $\mathrm{O}_{2}^{-}$is inhibited by TGF $\beta^{71}$ and thereby the formation of the highly toxic peroxynitrite is prevented.

TGF $\beta$ is a chemotactic agent for monocytes and macrophages and is suggested to be important in the recruitment of circulating monocytes into brain tissue after damage. ${ }^{336}$ TGF $\beta$ has protective effects in different experimental autoimmune diseases ${ }^{337-339}$ whereas neutralizing antibodies to TGF $\beta 1$ worsen clinical severity. ${ }^{340,341}$ During EAE, and after cerebral trauma or hypoxic-ischaemic damage, TGF $\beta$ expression is increased when neurological symptoms are

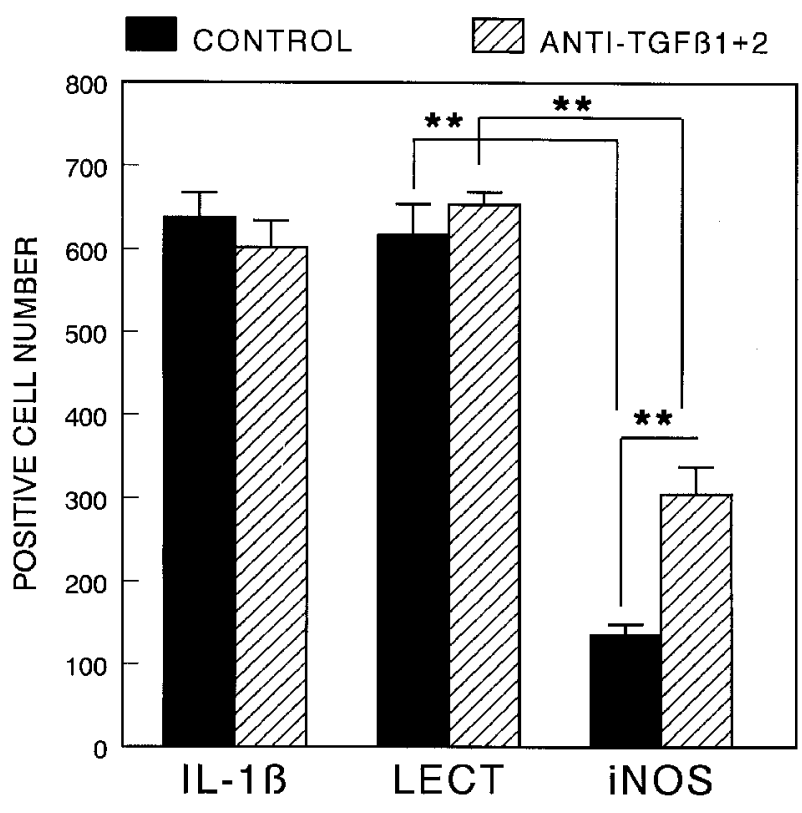

FIG. 5. Effect of immunoneutralizing of TGF $\beta 1$ and TGF $\beta 2$ on endotoxin induced expression of $\mathrm{IL}-1 \beta$ and iNOS by confluent mixed glial cell cultures containing mainly astroglial cells and microglial cells. Numbers of immunopositive cells in $24 \mathrm{~h}$ endotoxin $(1 \mu \mathrm{g} / \mathrm{ml})$ stimulated mixed glial cell cultures. Different cultures were stained with the microglial cell marker GSA-I-B4-isolectin (LECT) or for IL-1 $\beta$ or iNOS. Data are expressed as the mean and SE $(n=3) .{ }^{* *} P<$ 0.005 .

severe, which might indicate an inflammation limiting of TGF $\beta$ in the recovery phase thereby controlling the inflammatory reaction. ${ }^{342-345}$

Astroglial and microglial cells are known to constitutively produce TGF $\beta$ in vivo ${ }^{61,324,325}$ and in vitro. ${ }^{62,103-105,346,347}$ The is oforms TGF $\beta 1$, TGF $\beta 2$ and TGF $\beta 3$ are produced by astroglial cells in vitro, while microglial cells only produce the TGF $\beta 1$ isoform. ${ }^{60}$ TGF $\beta$ production in microglial and astroglial cells is increased after TNFa ${ }^{348}$ or IL-1 ${ }^{104,349}$ or TGF $\beta$ exposure itself. ${ }^{350}$

In co-cultures of astroglial cells and microglial cells bioactive TGF $\beta$ was found to inhibit iNOS expression and thereby NO production by endotoxin activated microglial cells. The presence of astroglial cells was show $n$ to be essential for the activation of TGF $\beta$ in these co-cultures of astroglial and microglial cells ${ }^{62}$ (see Fig. 5).

\section{Regulation of TGF $\beta$ activity}

TGF $\beta$ is produced by glial cells in a latent, inactive form $^{60}$ and forms a complex with the latencyassociated protein (LAP). ${ }^{351,352}$ Activation of latent TGF $\beta$ consists of releasing TGF $\beta$ from the LAP, which occurs after heat treatment, acidification, alkalization or proteolysis by plasmin. ${ }^{351,353}$ Plasmin is generated by the plasminogen activator system. Plasminogen activators (PA)s are serine proteases consisting of a $50 \mathrm{kD}$ urokinase-type plasminogen activator (u-PA) 


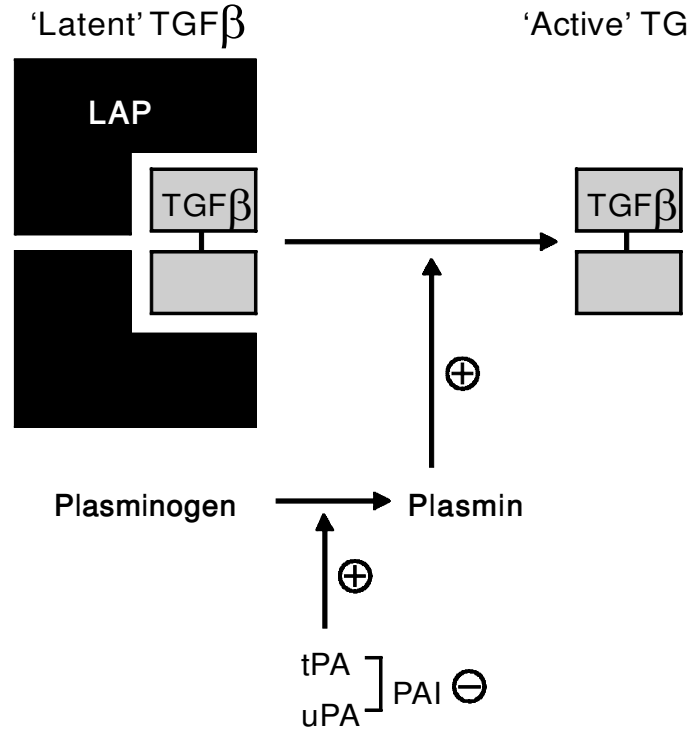

FIG. 6. Activation mechanism of latent TGF $\beta$ by plasmin Plasmin releases TGF $\beta$ from its latency associated protein (LAP) whereby active TGF $\beta$ is generated. Plasminogen is cleaved into plasmin by plasminogen activators i.e. urokinase PA (uPA) or tissue type PA (tPA) which are inhibited by plasminogen activators inhibitors (PAI).

and a $68 \mathrm{kD}$ tissue-type plasminogen activator (tPA), secreted as inactive pro-forms, which major substrate is plasminogen. UPA and tPA can cleave plasminogen into plasmin which subsequently activates latent $\operatorname{TGF}^{354,355}$ (Fig. 6). These PAs are specifically inhibited by the plasminogen activator inhibitors (PAI), PAI-1, PAI-2 and PAI-3 (Table 1), ${ }^{356,357}$ by formation of a tight complex with PAs.

Plasmin has a broad range of substrates including fibrin, fibronectin, laminin and matrix metalloproteinases (MMP). The PAs and PAIs play an important role by fine regulating the proteolytic degradation of fibrin

Table 1. Plasminogen activators and their inhibitors (adapted from Ref. 311)

\begin{tabular}{lcc}
\hline & \multicolumn{2}{c}{ Plasminogen activators (PAs) } \\
\cline { 2 - 3 } & $\begin{array}{c}\text { Pro form } \\
\text { molecular weight } \\
(\mathrm{kDa})\end{array}$ & $\begin{array}{c}\text { Active form } \\
\text { molecular weight } \\
(\mathrm{kDa})\end{array}$ \\
\hline uPA & 55 & 33.50 \\
tPA & 70 & 70 \\
\hline
\end{tabular}

Plasminogen activators inhibitors (PAls)

Molecular weight Substrate specificity $(\mathrm{kDa})$

\begin{tabular}{lcl}
\hline PAl-1 & $46-54$ & uPA=tPA \\
PAl-2 & $47-60$ & uPA>tPA \\
PAl-3 & 50 & uPA $>$ tPA \\
\hline
\end{tabular}

clots (fibrinolysis) in the circulation, mediated by plasmin ${ }^{354,358}$ and therefore tPA is now used for the treatment of thrombotic stroke. Only recently functions for PA were found in the brain, and proteolysis of the ex tracellular matrix (ECM) by MMP activation, amplified by PAs, has been suggested. The breakdow $\mathrm{n}$ of the ECM is thought to be involved in brain development and neurite outgrowth but also in neuropathology like growth and invasion of brain tumours, leukocyte infiltration in MS and EAE, breakdow $\mathrm{n}$ of the BBB and nerve demyelination. ${ }^{311}$

Microglial cells secrete proteases such as elastase, uPA and secrete plasminogen ${ }^{359,360}$ which have a direct neurotrophic effects on various types of neurones. ${ }^{361}$ Astroglial cells can synthesize and secrete both tPA and uPA as well as PAI-1, ${ }^{178,362-364}$ and tPA is involved in motor learning but also in Alzheimer's disease and neuronal degeneration. ${ }^{365-367}$ PAs and PAIs have been demonstrated in cerebrospinal fluid of patients with neurological disease $e^{368,369}$ and tPA expression was found ${ }^{370}$ in MS lesions supporting a role of PA and PAI in ne uropathological processes.

An important role of $\mathrm{PA}$ and $\mathrm{PAI}$ and the regulation ofTGF $\beta$ activity was show $n$ in a glial cell coculture. ${ }^{178}$ tPA and PAI-1 produced by astroglial cells regulated the bioactivity of TGF $\beta$, and thereby indirectly the production of NO by microglial cells. ${ }^{178}$ Therefore, we postulate that tPA-mediated activation of TGF $\beta$ plays an important role in neuroprotection.

\section{Summary}

In ne uropathological conditions such as Alzheimer's disease, Parkinson's disease, AIDS dementia complex and multiple sclerosis, activation of microglial cells and astroglial cells is evident. Under these neuropathological conditions cellular damage in the brain is considered to arise indirectly from cytotoxic substances produced by activated glial cells. One of these toxins is NO which has been demonstrated to be produced during several neuropathological conditions. High NO levels are produced by glial cells and exert neurotoxic effects. Astroglial cells and microglial cells communicate in various ways to reduce NO production by microglial cells which is essential to maintain homeostasis in the brain. The production of TGF $\beta$ by glial cells and its activation by astrocytederived tPA represents one mechanism by which astroglia limit $\mathrm{NO}$ production in the brain.

\section{References}

1. Virchow R. Ueber das Granulierte ansehen der Wandungen der Gehirnventrikel. Allg Z Psychiatrie 1846; 3: 242-250.

2. Somjen GG. Nervenkitt: notes on the history of the concept of ne uroglia. GLIA 1988; 1: 2-9.

3. Itagaki S, McGeer PL, Akiyama H, Zhu S, Selkoe D. Relationship of microglia and astrocytes to amyloid deposits of Alzheimer's disease. I Neuroimm unol 1989; 24: 173-182. 
4. McGeer PL, Akiyama H, Itagaki S, McGeer EG. Immune system response in Alzheimer's disease. Can J Neurol Sci 1989; 16: 519-527.

5. McGeer PL, Itagaki S, Boyes BE, McGeer EG. Reactive microglia are positive for HLA-DR in the substantia nigra of Parkinson's and Alzheimer's disease brains. Neu rology 1988; 38: 1285-1291.

6. McGeer PL, Itagaki S, Tago H, McGeer EG. Reactive microglia in patients with senile dementia of the Alzheimer type are positive for the histocompatibility glycoprotein HLA-DR. Neurosci Lett 1987; 79: $195-200$.

7. Rozemuller JM, Eikelenboom P, Pals ST, Stam FC. Microglial cells around amyloid plaques in Alzheimer's disease express leucocyte adhesion molecules of the LFA-1 family. Neurosci Lett 1989; 101: 288-292.

8. Woodroofe MN, Bellamy AS, Feldman M, Davison AN, Cuzner ML. Immunocytochemical characterization of the immune reaction in the central nervous system in multiple sclerosis. Possible role for microglia in lesion grow th. J Neurol Sci 1986; 74: 135-152.

9. Koka P, He K, Zack JA, Kitchen S, Peacock W, Fried I, et al. Human immunodeficiency virus 1 envelope proteins induce interleukin 1 , tumor necrosis factor alpha, and nitric oxide in glial cultures derived from fetal, neonatal, and adult human brain. J Exp Med 1995; 182: 941-952.

10. Dickson DW, Lee SC, Hatch W, et al. Macrophages and microglia in HIVrelated CNS neuropathology. In: Price RW, Perry SW, eds. HIV, AIDS and the Brain. New York: Raven Press, 1994; 99-118.

11. Giulian D, Yu J, Li X, Tom D, Li J, Wendt E, et al. Study of receptormediated neurotoxins released by HIV-1-infected mononuclear phagocytes found in human brain. I Neurosci 1996; 16: 3139-3153.

12. Rio-Hortega P, Microglia. In: Penfield W, ed. Cytology and Cellular Pathology of the Nervous System, Vol. 2. New York: Hoeber, 1932 481-534.

13. Law son LJ, Perry VH, Dri P, Gordon S. Heterogene ity in the distribution and morphology of microglia in the normal, adult mouse brain. Neuroscience 1991; 39: 151-170.

14. Murabe Y, Sano Y. Morphological studies on neuroglia. Cell Tissue Res 1982; 225: 469-485.

15. Ling E, Wong W. The origin and nature of ramified and amoeboid microglia: a historical review and current concepts. GLIA 1993; 7: $9-18$.

16. Boya J, Calvo JL, Carbonell AL, Borregon A. A lectin his tochemistry study on the development of rat microglial cells. J Anat 1991; 175: 229-236.

17. Murabe Y, Sano Y. Morphological studies on ne uroglia. VII. Distribution of 'brain macrophages' in brains of neonatal and adult rats, as determined by means of immunohistochemistry. Cell Tissue Res 1983; 229: 85-95.

18. Perry VH, Hume DA, Gordon S. Immunohis tochemical localization of macrophages and microglia in the adult and developing mouse brain. Neuroscience $1985 ; 15$ : 313-326.

19. Marty S, Dusart I, Peschanski M. Glial changes following an excitotoxic lesion in the CNS-Microglia macrophages. Neuroscience 1991; 45 529-539.

20. Leong S, Ling E. Amoeboid and ramified microglia: their interrelationship and response to brain injury. GLIA $1992 ; \mathbf{6}: 39-47$.

21. Killackey HP. Glia and the elimination of transient cortical projections. Trends Neurosci 1984; 7: 225-226.

22. Giulian D, Chen J, Ingeman JE, George JK, Naponen M. The role of mononuclear phagocytes in wound healing after traumatic injury to adult mammalian brain. I Neurosci 1989; 9: 4416-4429.

23. Stoll G, Trapp BD, Griffin JW. Macrophage function during Wallerian degeneration of rat brain optic nerve: clearance of degenerating myelin and la expression. J Neurosci 1989; 9: 2327-2335.

24. Murabe Y, Ibata Y, Sano Y. Morphological studies on neuroglia. III. Macrophage response and 'microgliocytosis' in kainic acid-induced lesions. Cell Tissue Res 1981; 218: 75-85.

25. Fujita S, TsuchihashiY, Kitamura T. Origin, morphology and function of the microglia. Prog Clin Biol Res 1981; 59A: 141-169.

26. Imamoto $K$. Origin of microglia: cell transformation from blood monocytes into macrophagic ameboid cells and microglia. Prog Clin Biol Res 1981; 59A: 125-139.

27. Hickey WF, Kimura H. Perivascular microglial cells of the CNS are bone marrow-derived and present antigen in vivo. Science 1988; 239 $290-292$.

28. Hickey WF, Vass K, Lassmann H. Bone marrow-derived elements in the central nervous system: an immunohistochemical and ultrastructura survey of rat chimeras. J Neuropathol Exp Neurol 1992; 51: 246-256.

29. De Groot CJA, Huppes W, Sminia T, Kraal G, Dijkstra CD. Determination of the origin and nature of brain macrophages and microglial cells in mouse central nervous using non-radioactive in situ hybridization and immunoperoxidase techniques. GLIA 1992; 6: 301-309.

30. Matsumoto Y, Fujiw ara M. Absence of donor-type major his tocompatibility complex class I antigen bearing microglia in the rat central nervous system of radiation bone marrow chimeras. J Neuro im munol 1987; 17: $71-82$.

31. Ting JP, Nix on DF, We iner LP, Frelinger JA. Brain la antigens have a bone marrow origin. Im munogenetics 1983; 17: 295-301.

32. Schultze B, Korr H. Cell kinetic studies of different cell types in the developing and adult brain of the rat and the mouse: a review. Cell
Tissue Kinet 1981 ; 14: 309-325.

33. Graeber MB, Tetzlaff W, Streit WJ, Kreutzberg GW. Microglial cells but not astrocytes undergo mitosis following rat facial nerve axotomy. Neurosci Lett 1988; 85: 317-321.

34. Alliot F, Lecain E, Grima B, Pessac B. Microglial progenitors with a high proliferative potential in the embryonic and adult mouse brain. Proc Natl Acad Sci USA 1991; 88: 1541-1545.

35. Laws on LJ, Perry VH, Gordon S. Turnover of resident microglia in the normal adult mouse brain. Neuroscience 1992; 48: 405-415.

36. Streit WJ, Graeber MB, Kreutzberg GW. Functional plasticity of microglia: a review. GLIA 1988; 1: 301-307.

37. Lassmann H, Schmied M, Vass K, Hickey WF. Bone marrow derived elements and resident microglia in brain inflammation. GLIA 1993; 7: $19-24$.

38. Kibayashi K, Mastri AR, Hirsch CS. Ne uropathology of human immunodeficiency virus infection at different disease stages. Hum Pathol 1996; 27: $637-642 \mathrm{i}$

39. Budka H, Costianzi G, Cristina A, Lechi A, Parravicini C, Trabattoni R, et al. Brain pathology induced by infection with the human immunodeficiency virus (HIV). A histological, immunocytochemical, and electron microscopical study of 100 autopsy cases. Acta Neuropathol 1987; 75 $185-198$.

40. Calvo C, Yoshimura T, Gelman M, Mallat M. Production of monocyte chemotactic protein-1 by rat brain macrophages. Eur J Neurosci 1996; 8: $1725-1734$

41. Frei K, Siepl C, Groscurth P, Bodmer S, Fontana A. Immunobiology of microglial cells. Ann NY Acad Sci 1987; 540: 218-227.

42. Perry VH, Gordon S. Macrophages and microglia in the nervous system. TINS 1988; 11: 273-277.

43. Perry VH, Gordon S. Modulation of CD4 antigen on macrophages and microglia in rat brain. J Exp Med 1987; 166: 1138-1143

44. Bo L, Mork S, Kong PA, Nyland H, Pardo CA, Trapp BD. Detection of MHC class II-antigens on macrophages and microglia, but not on astrocytes and endothelia in active multiple sclerosis lesions. J Neuroim munol 1994; 51: 135-146.

45. Tooyama I, Kimura H, Akiyama H, McGeer PL. Reactive microglia ex press class I and class II major histocompatibility complex antigens in Alzheimer's disease. Brain Res 1990; 523: 273-280.

46. McRae A, Gilland E, Bona E, Hagberg H. Microglia activation after neonatal hypoxic-ischaemia. Dev Brain Res 1995; 84: 245-252.

47. Suzumura A, Sawada M, Marunouchi R, Yamamoto H. Proliferation of microglia with IL-4. Neuro im munol 1993; 1: 248-263.

48. Oehminchen M. Inflammatory cells in the central nervous system: an integrating concept based on recent research in pathology, immunol ogy, and forensic medicine. In: Progress in Neuropathology. New York: Raven Press, 1983; 277-296.

49. Yao J, Harvath L, Gilbert DL, Colton CA. Chemotaxis by a CNS macrophage, the microglia. J Neurosci $1990 ; 27$ : 36-42.

50. Giulian D, Baker TJ, Shih LN, Lachman LB. Interleukin 1 of the central nervous system is produced by ameboid microglia. J Exp Med 1986; 164: 594-604

51. Vincent VAM, Van Dam A-M, Persoons JHA, Schotanus K, Steinbusch HWM, Schoffelmeer ANM, et al. Gradual inhibition of inducible nitric oxide synthase but not of interleukin- $\beta$ production in rat microglial cells of endotoxin-treated mixed glial cell cultures. GLIA 1996; 17: 94-102.

52. Yao J, Keri JE, Taffs RE, Colton CA. Characterization of interleukin-1 production by microglia in culture. Brain Res 1992; 591: 88-93.

53. Hetier E, Ayala J, De nefle P, Bousseau A, Rouget P, Mallat M, et al. Brain macrophages synthesize in terle ukin-1 and in terleukin-1 mRNAs in vitro. I Neurosci Res 1988; 21: 398-397.

54. Hetier E, Ayala J, Bousseau A, Prochiantz A. Modulation of interleukin-1 and tumor necrosis factor expression by $\beta$-adrene rgic agonists in mouse ameboid microglial cells. Exp Brain Res 1991; 86: 407-413.

55. Griffin WS, Stanley LC, Ling C, White L, MacLeod V, Perrot LJ, et al. Brain interleukin 1 and $S-100$ immunoreactivity are elevated in down syndrome and Alzheimer's disease. Proc Natl Acad Sci USA 1989; 86 7611-7615.

56. Saw ada M, Kondo N, Suzumura A, Marunouchi T. Production of tumour necrosis factor-alpha by microglia and astrocytes in culture. Bra in Res 1989; 491: 394-397

57. Chao CC, Hu S, Close K, Choi CS, Molitor TW, Novick WJ, et al. Cytokine release from microglia: differential inhibition by pentoxifylline and dexametasone. J Infect Dis 1992; 166: 847-853.

58. Sebire G, Emilie D, Wallon C, Hery C, Devergne O, Delfraissy J, et al. In vitro production of IL-6, IL-1 $\beta$, and tumor necrosis factor-alpha by human embryonic microglial and neural cells. J Im m unol 1993; 150 1517-1523.

59. Lee SC, Liu W, Dickson DW, Brosnan CF, Berman JW. Cytokine production by human fetal microglia and astrocytes. J Im munol 1993; 150: 2659-2667.

60. Constam DB, Philipp J, Malipiero UV, ten Rijke P. Differential expression of transforming grow th factor $\beta 1,-\beta 2$, and $-\beta 3$ by glioblastoma cells, astrocytes, and microglia. J Im munol 1992; 148: 1404-1410.

61. Kiefer R, Gold R, Gehrmann J, Lindholm D, Wekerle H, Kreutzberg GW. Transforming grow th factor beta expression in reactive spinal cord microglia and meningeal inflammatory cells during experimental 
allergic neuritis. J Neurosci Res 1993; 36: 391-398

62. Vincent VAM, Tilders FJH, Van Dam A-M. Inhibition of endotoxininduced nitric oxide synthase production in microglial cells by the presence of astroglial cells: a role for transforming grow th factor $\beta$ GLIA 1997; 19: 190-198.

63. Minghetti L, Polazzi E, Nicolini A, Creminon C, Levi G. Interferongamma and nitric oxide down-regulate lipopolysaccharide-induced prostanoid production in cultured rat microglial cells by inhibiting cyclooxygenase-2 expression. J Neurochem 1996; 66: 1963-1970.

64. Giulian D, Corpuz M, Richmond B, Wendt E, Hall ER. Activated microglia are the principal source of thromboxane in the central nervous system. Neurochem Int 1996; 29: 65-76.

65. Matsuo M, HamasakiY, Fujiyama F, Miyazaki S. Eicosanoids are produced by microglia, not by astrocytes, in rat glial cell cultures. Brain Res 1995; 685: 201-204.

66. Saw ada M, Suzumura A, Itoh Y, MarunouchiT. Production of interleukin5 by mouse astrocytes and microglia in culture. Neurosci Lett 1993 155: $175-178$.

67. Williams K, Dooley N, Ulvestad E, Becher B, Antel JP. IL-10 production by adult human derived microglial cells. Neurochem Int 1996; 29: 55-64.

68. Mizuno T, Sawada M, Marunouchi T, Suzumura A. Production of interleukin-10 by mouse glial cells in culture. Biochem Biophys Res Commun 1994; 205: 1907-1915.

69. Cunha FQ, Moncada S, Liew FY. Interleukin-10 (IL-10) inhibits the induction of nitric oxide synthase by interferon-gamma in murine macrophages. Biochem Biophys Res Comm 1992; 182: 1155-1159.

70. Oswald IP, Gazzinelli RT, Sher A, James SL. IL-10 synergizes w ith IL-4 and transforming grow th factor $\beta$ to inhibit macrophage cytotoxic activity. J Im m unol 1992; 148: 3578-3582.

71. Hu S, Sheng WS, Peterson PK, Chao CC. Cytokine modulation of murine microglial cell superoxide production. GLIA 1995; 13: 45-50.

72. Raff MC, Abney ER, Miller RH. Tw o glial cell line ages diverge prenatally in the rat optic nerve. Dev Biol 1984; 106: 53-64.

73. Cameron RS, Rakic P. Glial cell lineage in the cerebral cortex: a review and synthesis. GLIA 1991; 4: 124-137.

74. Misson J, Takahashi T, Caviness VS Jr. Ontogeny of radial and other astroglial cells in murine cerebral cortex. GLIA 1991; 4: 138-148.

75. Goldman JE, Vaysse PJ. Tracing glial cell lineages in the mammalian forebrain. GLIA 1991; 4: 149-156.

76. Noble M. Points of controversy in the $0-2 \mathrm{~A}$ lineage: clocks and type-2 astrocytes. GLIA 1991; 4: 157-164.

77. Martin PM, O'Callaghan JP. A direct comparison of GFAP immunocytoche mistry and GFAP concentration in various regions of eth anol-fixed rat and mouse brain. I Neurosci Meth 1995; 58: 181-192.

78. Eng LF, DeArmond SJ. Immunocytochemical studies of astrocytes in normal development and disease. Adv Cell Neurobiol 1982; 3 $145-171$.

79. Akimoto J, Itoh H, Miwa T, Ikeda K. Immunohistochemical study of glutamine synthetase expression in early glial development. Dev Bra in Res 1993; 72: 9-14.

80. Caldini M, Rolland B, Fages C, Tardy M. Glutamine synthetase activity during mouse brain development. Experientia 1982; 38: 1199-1202.

81. Shehab SAS, Cronly-Dillon JR, Nona SN, Stafford CA. Preferential histochemical staining of protoplasmic and fibrous astrocytes in rat CNS with GFAP antibodies using different fixatives. Brain Res 1990; 518: 347-352.

82. Miller RH, Raff MC. Fibrous and protoplasmic astrocytes are biochemically and developmentally distinct. J Neurocytol 1984; 15 187-192.

83. Ogaw a M,Araki M, Nagatsu I,Yoshida M. Astroglial cell alteration caused by neurotox ins: immunohistochemical observations with antibodies to glial fibrillary acidic protein, laminin, and tyrosine hydroxylase. Exp Neur 1989; 106: 187-196.

84. Dell'Anna ME, Geloso MC, Draisci G, Luthman J. Transient changes in Fos and GFAP immunoreactivity precede neuronal loss in the rat hippocampus following neonatal anoxia. Exp Neur 1995; 131 $144-156$.

85. O'Callaghan JP. Assessment of neurotoxicity: use of glial fibrillary acidic prote in as a biomarker. Biomed Environ Sci 1991; 4: 197-206.

86. O'Callaghan JP, Jensen KF. Enhanced expression of glial fibrillary acidic protein and the cupric silver degeneration reaction can be used as sensitive and early indicators of neurotoxicity. Neuro Tox 1992; 13: $113-122$

87. Levi-Montalcini R, Angletti PU. Nerve grow th factor. Physiol Rev 1968 48: $534-569$

88. Gonzalez D, Les Dees W, Kiney JK, Ojeda SR, Saneto RP. Expression of $\beta$-nerve grow th factor in cultured cells derived from the hypothalamus and cerebral cortex. Bra in Res 1990; 511: 249-258.

89. Friedman WJ, Larkfors J, Ayer-le-Lievre C, Ebendal T, Olson L, Persson H. Regulation of beta nerve growth factor expression by inflammatory mediators in hippocampal cultures. J Neurosci Res 1990; 27: $374-382$.

90. Lindholm D, Heumann R, Meyer M, Thoenen H. Interleukin-1 regulates synthesis of nerve grow th factor in non-neuronal cells of rat sciati nerve. Nature 1987; 330: 658-659.

91. Bandtlow CE, Meyer M, Lindholm D, Sprangler M, Heuman R, Thoenen
H. Regional and cellular codistribution of interleukin-1 be ta and nerve grow th factor mRNA in the adult rat brain: possible relationship to the regulation of nerve grow th factor synthesis. J Cell biol 1990; 111 1701-1711.

92. Spranger M, Lindholm D, Bandtlow C, Heumann R, Gnahn H, NaherNoe M, et al. Regulation of nerve grow th factor (NGF) synthesis in the rat central nervous system: comparison between the effects of interleukin-1 and various grow th factors in astrocyte cultures in vivo. Eur J Neurosci 1990; 2: 69-76.

93. Gadient RA, Cron KC, Otten U. Interleukin-1 $\beta$ and tumor necrosis factor-alpha synergistically stimulate nerve grow th factor (NGF) release from cultured rat astrocytes. Neurosci Lett 1990; 117: 335-340.

94. Awatsuji H, Furukaw a Y, Hirota M, MurakamiY, Nii S, Furakawa S, et al. Interleukin -4 and -5 as modulators of nerve grow th factor synthesis/ secretion in astrocytes. I Neurosci Res 1993; 34: 539-545.

95. Rudge JS, Pasnikowski EM, Hoslst P, Lindsay RM. Changes in neurotrophic factor expression and receptor activation follow ing exposure of hippocampal neuron/astrocyte cocultures to kainic acid. J Neurosci 1995; 15: 6856-6867.

96. Mocchetti I, Wrathall JR. Neurotrophic factors in central nervous system trauma. I Neurotrauma $1995 ; 12$ : 853-870.

97. Fontana A, Kristensen F, Dubs R, Gemsa D, Weber E. Production of prostaglandin E and an interleukin-1 like factor by cultured astrocytes and C6 glioma cells. I Im m unol 1982; 129: 2413-2419.

98. Nieto-Sampedro M, Berman MA. Interleukin-1-like activity in rat brain: sources, targets, and effect of injury. J Neurosci Res 1987; 17: $214-219$.

99. Fontana A, Grob PJ. Astrocyte-derived interleukin-1-like factors. Lymph Res 1984; 3: 11-16.

100. Fontana A, McAdam KPWJ, Kristensen F, Weber E. Biological and biochemical characterization of an interleukin 1 like factor from rat C6 glioma cells. Eur J Immunol 1983; 13: 685-689.

101. Sawada M, Suzumura A, Marunouchi T. TNF-alpha induces IL-6 production by astrocytes but not by microglia. Brain Res 1992; 583 296-299.

102. Frei K, Bodmer S, Schwerdel C, Fontana A. Astrocytes of the brain synthesize Interleukin 3-like factors. J Immunol 1985; 135 4044-4047

103. da Cunha A, Jackson RW, Vitkovic L. HIV-1 non-specifically stimulates production of transforming growth factor- $\beta 1$ transfer in primary astrocytes. J Neuro im munol 1995; 60: 125-133.

104. da Cunha A, Vitkovic L. Transforming grow th factor-beta 1 (TGF $\beta 1$ ) expression and regulation in rat cortical astrocytes. J Neuroim muno 1992; 36: 157-169.

105. Morganti-Kossmann MC, Kossmann T, Brandes ME, Mergenhagen SE Wahl SM. Autocrine and paracrine regulation of astrocyte function by transforming grow th factor- $\beta$. J Neuroimmunol 1992; 39 $163-174$.

106. Lee SC, Dickson DW, Brosnan CF. Interleukin-1, nitric oxide and reactive astrocytes. Brain Behav Im mun 1995; 9: 345-354.

107. Moline-Holgado F, Lledo A, Guaza C. Evidence for cyclooxygenase activation by nitric oxide in astrocytes. GLIA 1995; 15: 167-172.

108. Brenner T, Yamin A, Abramsky O, Gallily R. Stimulation of tumor necrosis factor-alpha production by mycoplasmas and inhibition by dexametasone in cultured astrocytes. Brain Res 1993; 608: 273-279.

109. Giulian D, Vaca K, Johnson B. Secreted peptides as regulators of ne uron glia and glia-glia interactions in the developing nervous system. $J$ Neurosci Res 1988; 21 : 487-500.

110. Lee SC, Brosnan CF, Dickson DW. GM-CSF promotes proliferation of human fetal and adult microglia in primary cultures. GLIA 1994; 12 309-318.

111. Giulian D, Johnson B, Krebs JF, George JK, Tapscott M. Microglial mitogens are produced in the developing and injured mammalian brain. I Cell Biol 1991; 112: 323-333.

112. Lafortune L, Nalbantoglu J, Antel JP. Expression of tumor necosis factor alpha (TNF alpha) and interleukin 6 (IL-6) mRNA in adult human astrocytes: comparison with adult microglia and fetal astrocytes. Neuropathol Exp Neurol 1996; 55: 515-521.

113. Aloisi F, Borsellino G, Samoggia P, Testa U, Chelucci C, Russo G, et al. Astrocyte cultures from human embryonic brain: characterization and modulation of surface molecules by inflammatory cytokines. J Neurosci Res 1992; 32: 494-506

114. Fontana A, Fierz W, Wekerle H. Astrocytes present myelin basic prote in to encephalitogenic T-cell lines. Nature 1984; 307: 273-276.

115. Lassmann H, Vass K, Brunner C, Seitelberger F. Characterization of inflammatory infiltrates in experimental allergic encephalomyelitis. Progr Neuropathol 1986; 6: 33

116. Giulian D, Woodward J, Young DG, Krebs JF, Lachman LB. Interleukin-1 injected into mammalian brain stimulates astrogliosis and ne ovascularization. J Neurosci 1988; 8: 2485-2490.

117. Giulian D, Young DG, Woodward J, Brown DC, Lachman LB. Interleukin1 is an astroglial grow th factor in the developing brain. J Neurosci 1988 ; 8: 709-714

118. Giulian D, Tapscott MJ. Immunoregulation of cells within the central nervous system. Brain, Behavior and Im m unity 1988; 2: 352-358.

119. Giulian D, Baker TJ. Peptides released by ameboid microglia regulate astroglial proliferation. J Cell Biol 1985; 101: 2411-2415. 
120. Giulian D, Lachman LB. Interleukin-1 stimulation of astroglial proliferation after brain injury. Science 1985; 228: 497-499.

121. Berkenbosch F. Macrophages and astroglial interactions in repair to brain injury. Ann NY Acad Sci USA 1992; 650: 186-190.

122. Giulian D, Li J, Li X, George J, Rutecki PA. The impact of microgliaderived cytokines upon gliosis in the CNS. Dev Neurosci 1994; 16: $128-136$.

123. Frei K, Bodmer S, Schwerdel C, Fontana A. Astrocyte-de rived interleukin 3 as a grow th factor for microglial cells and peritoneal macrophages. $J$ Im munol 1986; 137: 3521-3527.

124. Thery C, Stanley ER, Mallat M. Interleukin 1 and tumor necrosis factoralpha stimulate the production of colony-stimulating factor 1 by murine astrocytes. J Neurochem 1992; 59: 1183-1186.

125. Liu W, Brosnan CF, Dickson DW, Lee SC. Macrophage colony-stimulating factor mediates astrocyte-induced microglial ramification in human fetal central nervous system culture. Am J Pathol 1994; 145: 48-53.

126. Giulian D, Ingeman JE. Colony-stimulating factors as promotors of ameboid microglia. J Neurosci 1988; 8: 4707-4717.

127. Sawada M, Suzumura A, Yamamoto H, Marunouchi T. Activation and proliferation of the isolated microglia by colony stimulating factor-1 and possible involvement of protein kinase C. Brain Res 1990; 509 $119-124$.

128. Suzumura A, MarunouchiT, Yamamoto H. Morphological transformation of microglia in vitro. Brain Res 1991; 545: 301-306.

129. Tanaka J, Maeda N. Microglial ramification requires nondiffusible factors derived from astrocytes. Exp Neurol 1996; 137: 367-375.

130. Sievers J, Parwaresch R, Wottge H. Blood monocytes and spleen macrophages differentiate into microglia-like cells on monolayers of astrocytes: morphology. GLIA 1994; 12: 245-258.

131. Schmidtmayer J, Jacobsen C, Miksch G, Sievers J. Blood monocytes and spleen macrophages differentiate into microglia-like cells on monolayers of astrocytes: membrane currents. GLIA 1994; 12 $259-267$.

132. Griffin WST, Stanley LC, Ling C, White L, MacLeod V, Perrot LJ, et al. Brain interleukin-1 and S-100 immunoreactivity are elevated in Down syndrome and Alzheimer disease. Proc Natl Acad Sci USA 1989; 86 7611-7615.

133. Hertz L. Neuronal-astrocytic interactions in brain development, brain function and brain disease. Adv Exp Med Biol 1991; 296 $143-159$.

134. Brenneman DE, Schultzberg M, Bartfai T, Gozes I. Cytokine regulation of neuronal survival. J Neu rochem 1992; 58: 454-460.

135. Vaca K, Wendt E. Divergent effects of astroglial and microglial secretions on neuron growth and survival. Exp Neurol 1992; 118 $62-72$.

136. Langeveld CH, Jongenelen CAM, Schepens E, Stoof JC, Bast A, Drukarch B. Cultured rat striatal and cortical astrocytes protect mesencephalic dopamine rgic neurons against hydrogen peroxide toxicity independen of their effect on neuronal development. Neurosci Lett 1995; 192 $13-16$.

137. Garcia-Abreu J, Neto M, Carvalho SL, Cavalcante LA. Regionally specific properties of midbrain glia: I. Interactions with midbrain neurons. $J$ Neurosci Res 1995; 40: 471-477.

138. Dong JF, Detta A, Bakker MHM, Hitchcock ER. Direct interaction with target-derived glia enhances survival but not differentiation of human fetal mesencephalic dopaminergic neurons. Neuroscience 1993; 56 : 53-60.

139. Bowenkamp KE, Hoffman AF, Gerhardt GA, Henry MA, Biddle PT, Hoffner BJ, et al. Glial cell line-derived neurotrophic factor supports survival of injured midbrain dopaminergic neurons. J Comp Neurol 1995; 355: 479-489.

140. Banker GA. Trophic interactions between astroglial cells and hippocampal neurons in culture. Science 1980; 209: 809-810.

141. Noble M, Fok-Seang J, Cohen J. Glia are a unique substrate for the in vitro grow th of central nervous system neurons. J Neurosci 1984; 4: 1892-1903.

142. Schmalenbach C, Muller HW. Astroglia-neuron interactions that promote long-term neuronal survival. J Chem Neuroanat 1993; 6: 229-237.

143. Hatten ME, Mason CA. Neuron-astroglial interactions in vitro and in vivo. Trends Neuroscience 1986; 168-174.

144. Miller C, Tsatas O, David S. Dibutyryl cAMP, interleukin-1 $\beta$, and macrophage conditioned medium enhance the ability of astrocytes to promote neurite grow th. J Neurosci Res 1994; 38: 56-63.

145. Dugan L, Bruno VMG, Amagasu SM, Giffard RG. Glia modulate the response of murine cortical neurons to excitotoxicity: glia exacerbate AMPA neurotoxicity. J Neurosci 1995; 15: 4545-4555.

146. Swanson RA, Choi DW. Glial glycogen stores affect neuronal survival during glucose deprivation in vitro. J Cereb Bood Flow Metab 1993; 13: $162-169$.

147. Kimelberg HK, Norenberg MD. Astrocytes. Sci Am 1989; April: 44-52.

148. Johnston PV, Roots Bl. Neuron-glial relationships. In: Handbook of Clinical Neurology. Amsterdam: North-Holland, 1976; 401-421.

149. Nagata K, Takei N, Nakajima K, Saito H, Kohsaka S. Microglial conditioned medium promotes survival and development of cultured mesencephalic neurons from embryonic rat brain. J Neurosci Res 1993;
34: 357-363.

150. Mallat M, Houlgatte R, Brachet P, Prochiantz A. Lipopolysaccharidestimulated rat brain macrophages rele ase NGF in vitro. Dev Biol 1989; 133: 309-311.

151. Chamak B, Dobbertin A, Mallat M. Immunohistochemical detection of th rombospondin in microglia in the developing rat brain. Neuroscience 1995; 69: 177-187.

152. Chamak B, Morandi V, Mallat M. Brain macrophages stimulate neurite grow th and regeneration by secreting thrombospondin. J Neurosci Res 1994; 38: 221-233.

153. Shimojo M, Nakajima K, Takei N, Hamanoue M, Kohsaka S. Production of basic fibroblast growth factor in cultured rat brain microglia. Neurosci Lett 1991; 123: 229-231.

154. Araujo DM, Cotman CW. Basic FGF in astroglial, microglial, and neuronal cultures: characterization of binding sites and modulation of release by lymphokines and trophic factors. J Neurosci 1992; 12: 1668-1678.

155. Yoshida K, Kakihana M, Chen LS, Ong M, Baird A, Gage FH. Cytokine regulation of nerve grow th factor-mediated cholinergic neurotrophic activity synthesized by astrocytes and fibroblasts. J Neurochem 1992; 59: 919-931.

156. Yoshida K, Gage FH. Cooperative regulation of nerve grow th factor synthesis and secretion of fibroblasts and astrocytes by fibroblast grow th factor and other cytokines. Bra in Res 1992; 569: 14-25.

157. Merill JE. Tumor necrosis factor alpha, interleukin 1 and related cytokines in brain development: normal and pathological. Dev Neurosci 1992 ; 14: 1-10.

158. Strijbos PJLM, Rothwell NJ. Interleukin-1 $\beta$ attenuates excitatory amino acid-induced neurodegeneration in vitro: involvement of nerve grow th factor. I Neurosci $1995 ; 15$ : 3468-3474.

159. Hama T, Kushima Y, Miyamoto M, Kubota M, Takei N, Hatanaka H. Interleukin-6 improves the survival of mesencephalic catecholaminergic and septal cholinergic neurons from postnatal two-week-old rats in cultures. Neuroscience 1991; 40: 445-452.

160. Akaneya $Y$, Takahishi $M$, Hatanaka H. Interleukin-1 $\beta$ enhances survival and interleukin- 6 protects against MPP+ neurotoxicity in cultures of fetal rat dopaminergic neurons. Exp Neurol 1995; 136: 44-52.

161. Giulian D, Corpuz M. Microglial secretion products and the ir impact on the nervous system. Adv Neurol 1993; 59: 315-320.

162. Giulian D, Vaca K, Noonan CA. Secretion of neurotoxins by mononuclear phagocytes infected with HIV-1. Science 1990; 250 $1593-1596$

163. Aswell K. The distribution of microglia and cell death in the fetal rat forebrain. Dev Brain Res 1991; 58: 1-12.

164. Hume DA, Perry VH, Gordon S. Immunohistochemical localization of a macrophage-specific antigen in developing mouse retina: phagocytosis of dying neurons and differentiation of microglial cells to form a regular array in the plex iform layers. J Cell Biol 1983; 97: 253-257.

165. Ferrer I, Bernet E, Soriano E, Del Rio T, Fonseca M. Naturally occurring cell death in the cerebral cortex of the rat and removal of dead cells by transitory phagocytes. Neuroscience 1990; 39: 451-458.

166. Innocenti GM, Clarke S, Koppel H. Transitory macrophages in the white matter of the developing visual cortex. II. Development and relations with axonal pathways. Dev Brain Res 1983; 11: 55-66.

167. Colton CA, Gilbert DL. Microglia, an in vivo source of reactive oxygen species in the brain. Adv Neurol 1993; 59: 321-326.

168. Van Muiswinkel FL, Veerhuis R, Eikelenboom P. Amyloid $\beta$ protein primes cultured rat microglial cells for an enhanced phorbol 12 -myristate 13-acetate-induced respiratory burst activity. J Neurochem 1996; 66: $2468-2476$.

169. Banati RB, Hoppe K, Gottmann K, Kreutzberg GW. Cytotoxicity of microglia. GLIA 1993; 30: 111-118.

170. Banati RB, Rothe G, Valet G, Kreutzberg GW. Detection of lysosomal cysteine proteinases in microglia: flow cytometric measurement and histochemical localization of cathepsin B and L. GLIA 1993; 7: 183-191.

171. Colton AC, Gilbert DL. Production of superoxide by a CNS macrophage, the microglia. FEBS Lett 1987; 223: 284-288.

172. Thery C, Chamak B, Mallat M. Free radical killing of neurons. Eur J Neurosci 1991; 3: 1155-1164.

173. Dickson DW, Lee SC, Mattiace LA, Yen S, Brosnan CF. Microglia and cytokines in neurological disease, with special reference to AIDS and Alzheimer's disease. GLIA 1993; 7: 75-83.

174. Chao CC, Hu S. Tumor necrosis factor-alpha potentiates glutamate neurotoxicity in human fetal brain cell cultures. Dev Neurosci 1994 ; 16: $172-179$

175. Piani D, Frei K, Quang Do K, Cuenod M, Fontana A. Murine brain macrophages induce NMDA receptor mediated neurotoxicity in vitro by secreting glutamate. Neurosci Lett 1991; 133: 159-162.

176. Thery C, Chamak B, Mallat M. Cytotoxic effect of brain macrophages on developing neurons. Eur J Neurosci 1991; 3: 1155-1164.

177. Stre it WJ. Microglial-ne uronal interactions. J Chem Neuro anat 1993; 6: 261-266.

178. Vincent VAM, Lowik CWGM, Verheijen JH, Tilders FJH, Van Dam A-M. Role of astrocyte-derived tissue-type plasminogen activator in the regulation of endotoxin stimulated nitric oxide production by microglial cells. GLIA 1998; 22: 130-137. 
179. Gower DB. Modifiers of steroid-hormone metabolism: a review of their chemistry, biochemistry and clinical applications. J Steroid Biochem 1974; 5: 501-523.

180. Giulian D. Reactive glia as rivals in regulating neuronal survival. GLIA 1993; 7: 102-110.

181. Furchgott RF, Zawadzki JV. The obligatory role of endothelial cells in the relaxation of arterial smooth muscle by acetylcholine. Nature 1980 288: $373-376$.

182. Marletta MA. Nitric oxide synthase structure and mechanism. J Biol Chem 1993; 268: 12231-12234

183. Janssens SP, Shimouchi A, Quertermous T, Bloch DB, Block KD. Cloning an ex pression of a cDNA encoding human endothelium-derived relaxing factor/nitric oxide synthase. J Biol Chem 1992; 267: 14519-14522.

184. Forstermann U, Schmidt HHHW, Pollock JS, Sheng H, Mitchell JA Warner TD, et al. Isoforms of nitric oxide synthase. Characterization and purification from different cell types. Biochem Pharmacol 1991 42: 1849-1857.

185. Murphy S, Simmons ML, Agullo L, Garcia A, Feinstein DL, Galea E, et al. Synthesis of nitric oxide in CNS glial cells. Trends Neurosci 1993; 16 $323-328$.

186. Bredt DS, Snyder SH. Nitric oxide, a novel neuronal messenger. Neuro 1992; 8: 3-11.

187. Snyder SH. Nitric oxide: first in a new class of neurotransmitters? Science 1992; 257: 494-496.

188. Ignarro LJ, Gold ME, Buga GM. Basic polyamino acids rich in arginine, lysine, or ornithine cause both enhancement of and refractoriness to formation of endothelium-derived nitric oxide in pulmonary artery and vein. Circ Res 1989; 64: 315-329.

189. Tzeng TB, Fung HL. Pharmacodynamic modeling of the in vitro vasodilating effects of organic mononitrates. J Pharmacokinet Bio pharm 1992; 20: 227-251.

190. Holscher C, Rose PR. An inhibitor of nitric oxide synthesis prevents memory formation in the chick. Neurosci Lett 1992; 145: 165-167.

191. Hawkins RD. NO honey, I don't remember. Neuron 1996; 16 $465-467$.

192. Schuman EM, Madison DV. A requirement for the intercellular messenger nitric oxide in longterm potentiation. Science 1991; 254 1503-1506.

193. Ohno M, Yamamoto $T$, Watanabe $S$. Deficits in working memory following inhibition of hippocampal nitric oxide synthesis in the rat Brain Res 1993; 632: 36-40.

194. Bredt DS, Glatt CE, Hw ang PM, Fotuhi M, Daw son TM, Snyder SH. Nitric oxide synthase protein and mRNA are discretely localized in neuronal populations of the mammalian CNS toge the $r$ with NADPH diaphorase. Neuron 1991; 7: 615-624.

195. Benyo Z, Szabo C, Stuiver BT, Bohus B, Sandor P. Effect of chronic nitric oxide synthase blockade on local hypothalamic blood flow in rats. Neurosci Lett 1995; 198: 127-130.

196. Low enstein CJ, Glatt CS, Bredt DS, Snyder SH. Cloned and expressed macrophage nitric oxide synthase contrasts with the brain enzyme. Proc Natl Acad Sci USA 1992; 89: 6711-6715.

197. Green SJ, Nacy CA. Antimicrobial and immunopathologic effects of cytokine-induced nitric oxide synthesis. Curr Opin Infect Dis 1993; 6 384-396.

198. Nathan C. Nitric oxide as a secretory product of mammalian cells FASEB J 1992; 6: 3051-3064.

199. Marletta MA, Yoon PS, lyengar R, Leaf CD, Wishnik JS. Macrophage oxidation of L-arginine to nitrite and nitrate: nitric oxide is an intermediate. Biochem istry 1988; 27: 8706-8711.

200. Koprow ski H, Zheng YM, Heber-Katz E. In vivo expression of inducible nitric oxide synthase in experimentally induced neurologic diseases. Proc Natl Acad Sci USA 1993; 90: 3024-3027.

201. Bolanos JP, Heales SJ, Land JM, Clark JB. Effect of peroxynitrite on the mitochondrial respiratory chain: differential susceptibility of neuron and astrocytes in primary culture. J Neurochem 1995; 64: 1965-1972.

202. Boje KM, Arora PK. Microglial-produced nitric oxide and reactive nitrogen oxides mediate neuronal cell death. Brain Res 1992; 587: $250-256$.

203. Galea E, Feinstein DL, Re is DJ. Induction of calcium-independent nitric oxide synthase activity in primary rat glial cultures. Proc Natl Acad Sci USA 1992; 89: 10945-10949.

204. Iade cola C, Xu X, Zhang F, El-Fakahany E, Ross ME. Marked induction of calcium-independent nitric oxide synthase activity after focal cerebral ischemia. J Cereb Bood Flow Metab 1995; 15: 52-59.

205. Iadecola C, Zhang F, Xu S, Casey R, Ross ME. Inducible nitric oxide synthase gene expression in brain following cerebral ischemia. J Cereb Bood Flow Metab 1995; 15: 378-384.

206. Choi DW. Glutamate neurotoxicity and diseases of the nervous system. Neuron 1988; 1: 623-634.

207. Meldrum B, Garthwaite J. Excitatory amino acid neurotoxicity and neurodegenerative disease. Trends Pharmacol Sci 1990; 11: $379-387$

208. Garthwaite J. Glutamate, nitric oxide and cell-cell signalling in the nervous system. Trends Neurosci 1991; 14: 60-67.

209. Simonian NA, Coyle JT. Oxidative stress in neurodegenerative diseases. Annu Rev Pharmacol Toxicol 1996; 36: 83-106.
210. Zhang J, Snyder SH. Nitric oxide in the nervous system. Annu Rev Pharmacol Toxicol 1995; 35: 213-233.

211. Dawson TD, Daw son VL, Snyder SH. Molecular mechanisms of nitric oxide actions in the brain. Ann NY Acad Sci USA 1994; 738: 76-85.

212. Huang Z, Huang PL, Panahian N, Dalkara T, Fishman MC, Moskowit MA. Effects of cerebral ischemia in mice deficient in neuronal nitric oxide synthase. Science 1994; 265: 1883-1885.

213. Daw son VL, Daw son TM. Nitric oxide neurotoxicity. J Chem Neuroanat 1996; 10: 179-190.

214. Butz EA, Hostager BS, Southern PJ. Macrophages in mice acutely infected with lymphocytic choriomeningitis virus are primed for nitric oxide synthesis. Microbiol Pathogen 1994; 16: 283-295.

215. Campbell IL, Samii A, Chiang CS. Expression of inducible nitric oxide synthase. Correlation with neurology and clinical features in mice with lymphocytic choriomeningitis. J Im munol 1994; 153: 3622-3629.

216. Van Dam A-M, Bauer J, Man-A-Hing WKH, Marquette C, Tilders FJH, Berkenbosch F. Appearance of inducible nitric oxide synthase in the rat central nervous system after rabies virus infection and during experimental alle rgic encephalmyelitis but not after peripheral administration of endotoxin. J Neurosci Res 1995; 40: 251-260.

217. Zheng YM, Schafer MK, Weihe E, Sheng H, Corisdeo S, Fu ZF, et al. Severity of neurological signs and degree of inflammatory lesions in the brains of rats with Borna disease correlate $w$ ith the induction of nitric oxide synthase. J Virol 1993; 67: 5786-5791.

218. Korytko PJ, Boje KMK. Pharmacological characterization of nitric ox ide production in a rat model of meningitis. Neuropharmacology 1996 35: 231-237.

219. Gazzinelli RT, Eltoum I, Wynn TA, Sher A. Acute cerebral toxoplasmosis is induced by in vivo neutralization of TNF-alpha and correlates with the dow nregulated expression of inducible nitric oxide synthase and othe markers of macrophage activation. J Immunol 1993; 151 3672-3681.

220. Bo L, Dawson TM, Wesselingh S, Mork S, Choi S, Kong PA, et al. Induction of nitric oxide synthase in demyelinating regions of multiple regions of multiple sclerosis brains. Ann Neurol 1994; 36 781-786.

221. Merrill JE, Ignarro LJ, Sherman MP, Melinek J, Lane TE. Microglial cell cytotoxicity of oligodendrocytes is mediated through nitric oxide. Im munol 1993; 151: 2132-2141.

222. Chao CC, Hu S, Molitor TW, Shaskan EG, Peterson PK. Activated microglia mediate neuronal cell injury via a nitric oxide mechanism. J Im munol 1992; 149: 2736-2741.

223. Beckman JS, Beckman TW, Chen J, Marshall PA, Freeman BA. Apparent hydroxyl radical production by peroxynitrite: implications for endothelial injury from nitric oxide and superoxide. Proc Natl Acad Sci USA 1990; 87: 1620-1624.

224. Zhang J, Dawson VL, Daw son TM, Snyder SH. Nitric ox ide activation op poly (ADP-ribose) synthase in neurotoxicity. Science 1994; 263 687-689.

225. Bolanos JP, Peuchen S, Heales SJR, Land JM, Clark JB. Nitric ox ide mediated inhibition of the mitochondrial respiratory chain in cultured astrocytes. J Neurochem 1994; 63: 910-916.

226. Reif DW, Simmons RD. Nitric oxide mediates iron release from ferritin. Arch Biochem Biophys 1990; 283: 537-541.

227. Stuehr DJ, Nathan CF. A macrophage product responsible for cytostasis and respiratory inhibition in tumor target cells. J Exp Med 1989; 169 $1543-1555$.

228. Lipton SA, Singel DJ, Stamler JS. Nitric oxide in the central nervous system. Prog Br Res 1994; 103: 359-364.

229. Bonfoco E, Krainc D, Ankarcrona M, Nicotera P, Lipton S. Apoptosis and necrosis: two distinct events induced, respectively, by mild and intense insults with NMDA or nitric oxide/superoxide in cortical cell cultures. Proc Natl Acad Sci USA 1995; 92: 7162-7166.

230. Estevez AG, Radi R, Barbeito L, Shin JT, Thompson JA, Beckman JS Peroxynitrite-induced cytotoxicity in PC12 cells: evidence for an apoptotic mechanism differentially modulated by neurotrophic factors. I Neurochem 1995; 65: 1543-1550.

231. Mitrovic B, Ignarro LJ, Vinters HV, Akers MA, Schmid I, Uittenbogaart CL, et al. Nitric oxide induces necrotic but not apoptotic cells in oligodendrocytes. Neuroscience 1995; 65: 531-539.

232. Peunova N, Enikolopov G. Amplification of calcium-induced gene transcription by nitric oxide in neuronal cells. Nature 1993; 364 $450-453$.

233. Nicotera P, Bonfoco E, Brune B. Mechanisms for nitric oxide-induced cell death: involvement of apoptosis. Adv Neuroimm 1995; 5 411-420.

234. Dorheim MA, Tracey WR, Pollock JS, Grammas P. Nitric ox ide synthase activity is elevated in brain microvessels in Alzheimer's disease. Biochem Biophys Res Commun 1994; 205: 659-665.

235. Vodovotz Y, Lucia MS, Flanders C, Chesler L, Xie QS, Smith TW, Weidner $\mathrm{J}$, et al. Inducible nitric oxide synthase in tangle-bearing neurons of patients with Alzheimer's disease. J Exp Med 1996; 184: 1425-1433.

236. Sherman MP, Griscavage JM, Ignarro LJ. Nitric oxide-mediated ne uronal injury in multiple scle rosis. Med Hypotheses 1992; 39: 143-146.

237. Cross AH, Keeling RM, Goorha S, San M, Rodi C, Wyatt PS, et al. Inducible nitric oxide synthase gene expression and enzyme activity correlate with disease activity in murine experimental autoimmune 
encephalomyelitis. J Neuroim munol 1996; 71: 145-153.

238. Bagasra O, Michaels FH, Mu Zheng Y, Bobroski LE, Spitsin SV, Fang Fu Z, et al. Activation of the inducible form of nitric oxide synthase in the brains of patients with multiple sclerosis. Proc Natl Acad Sci USA 1995; 92: 12041-12045.

239. Brosnan CF, Battistini L, Raine CS, Dickson DW, Casedevall A, Lee SC. Reactive nitrogen intermediates in human neuropathology: an overview. Dev Neurosci 1994; 16: 152-161.

240. De Groot CJA, Ruuls SR, The euwes JWM, Dijkstra CD, Van der Valk P. Immunocytochemical characterization of the expression of inducible and constitutive isoforms of nitric oxide synthase in demyelinating multiple sclerosis lesions. J Neuropathol Exp Neurol 1997; 56 $10-20$.

241. Zhao W, Tilton RG, Corbett JA, Mc Daniel ML, Misko TP, Williamson JR, et al. Experimental allergic encephalomyelitis in the rat is inhibited by aminoguanidine, an inhibitor of nitric oxide synthase. J Neuroim munol 1996; 64: 123-133.

242. Beck J, Rondot P, Catinot L, Falcoff E, Kirchner H, Wietzerbin J. Increased production of interferon gamma and tumor necrosis factor precedes clinical manifestation in multiple sclerosis: do cytokines trigger off exacerbations. Acta Neurol Scand 1988; 78: 318-330.

243. Hofman FM, Hinton DR, Johnson K, Merrill JE. Tumor necrosis factor identified in multiple sclerosis brain. J Exp Med 1989; 170: 607-612.

244. Merrill JE, Strom SR, Ellison GW, Myers LW. In vitro study of mediators of inflammation in multiple sclerosis. J Clin Immunol 1989; 9: $84-96$.

245. Panitch HS, Hirsch RL, Schindler J, Johnson KP. Treatment of multiple sclerosis with gamma interferon: exacerbations associated with activation of the immune system. Neurology 1987; 37: 1097-1100.

246. Adamson DC, Wildemann B, Sasaki M, Glass JD, McArthur JC, Christov VI, et a $l$. Immunologic NO synthase: elevation in severe AIDS dementia and induction by HIV-1 gp41. Science 1996; 274: 1917-1920.

247. Nuovo GJ, Lynn Alfieri M. AIDS dementia is associated with massive, activated HIV-1 infection and concomitant expression of several cytokines. Mol Med 1996; 2: 358-366.

248. Lane TE, Buchmeier J, Watry DD, Fox HS. Expression of inflammatory cytokines and inducible nitric oxide synthase in brains of SIV-infected rhesus monkeys: applications to HIV-induced central nervous system disease. Mol Med 1996; 2: 27-37.

249. Vazeux R, Brousse N, Jarry A, Henin D, Marche C, Vedrenne C, et al. AIDS subacute encephalitis; identification of HIV-infected cells. Am J Pathol 1987; 126: 403-410.

250. Lee SC, Dickson DW, Liu W, Brosnan CF Induction of nitric oxide synthase activity in human astrocytes by interleukin-1 $\beta$ and interferongamma. J Neuroim munol 1993; 46: 19-24.

251. Maddon PJ, Dalgle ish AG, McDougal JS, Clampham PR, Weiss RA, Axel R. The T4 gene encodes the AIDS virus receptor and is expressed in the immune system and the brain. Cell 1986; 47: 333-348.

252. Genis P, Jett M, Bernton EW, Boyle T, Gelbard HA, Dzenko K, et al. Cytokines and arachidonic metabolites produced during human immunodeficiency virus (HIV)-infected macrophage-astroglia interactions: implications for the neuropathogenes is of HIV disease. J Exp Med 1992; 176: $1703-1718$.

253. Yeung MC, Pulliam L, Lau AS. The HIV envelope protein gp 120 is tox ic to human brain-cell cultures through the induction of interleukin-6 and tumor necrosis factor-alpha. AIDS 1995; 9: 137-143.

254. Epstein LG, Gendelman HE. Human immunodeficiency virus type 1 infection of the nervous system: pathogenetic mechanisms. Ann Neurol 1993; 33: 429-436.

255. Wiley CA, Achim CL, Schrier RD, Heyes MP, McCutchan JA, Grant I. Relationship of cerebrospinal fluid immune activation associated factors to HIV encephalitis. AIDS 1992; 6: 1299-1307.

256. Achim CL, Heyes M, Wiley CA. Quantitation of human immunodeficiency virus, immune activation factors, and quinolinic acid in AIDS brains. J Clin Invest 1993; 91: 2769-2775.

257. Pietraforte D, Tritarelli E, Testa U, Minetti M. Gp120 HIV envelope glycoprotein increases the production of nitric oxide in human monocyte-derived macrophages. J Leukoc Biol 1994; 55: 175-182.

258. Mollace V, Colasanti M, Persichini T, Bagetta G, Lauro GM, Nistico G. HIV gp120 glycoprotein stimulates the inducible isoform of NO synthase in human cultured astrocytoma cells. Biochem Biophys Res Com 1993 ; 194: 439-445.

259. Chao CC, Hu S, Sheng WS, Bu D, Bukrinsky MI, Peterson PK. Cytokinestimulated astrocytes damage human neurons via a nitric oxide mechanism. GLIA 1996; 16: 276-284.

260. Dawson VL, Bahmbhatt HP, Mong JA, Dawson TM. Expression of inducible nitric oxide synthase causes delayed neurotox icity in primary mixed neuronal-glial cortical cultures. Neuropharm acology 1994; 33: 1425-1430.

261. Dawson TM, Zhang J, Daw son VL, et al. Nitric oxide: cellular regulation and neuronal injury. In: Seil F, ed. Progress in Brain Research. Amsterdam: Elsevier Science, 1994; 365-369.

262. Wesselingh SL, Takahashi K, Glass KD, McArthur JC, Griffin JW, Griffin DE. Cellular localization of tumor necrosis factor mRNA in neurological tissue from HIV-infected patients by combined reverse transcriptase/ polymerase chain reaction in situ hybridization and immunohistochem- istry. J Im munol 1997; 74: 1-8.

263. Yoshioka M, Bradley WG, Shapshak P, Nagano I, Stewart RV, Xin K, et al. Role of immune activation and cytokine expression in HIV-1-associated neurologic diseases. Adv Neuro im munol 1995; 5: 335-358.

264. Perrella O, Finelli L, Carrieri PB. The role of cytokines in AIDS-dementia complex. Acta Neurologica 1992; 14: 342-344.

265. Sippy BD, Hofman FM, Wallach D, Hinton DR. Increased expression of tumor necrosis factor-alpha receptors in the brains of patients with AIDS. J AIDS Hum Retrovir 1995; 10: 511-521.

266. Bukrinsky MI, Nottet HSLM, Schmidtmayerova H, Dubrovsky L, Flanagan CR, Mullins ME, et al. Regulation of nitric oxide synthase activity in human immunodeficiency virus type 1 (HIV-1)-infected monocytes: implications for HIV-associated neurological disease. $J$ Exp Med 1995; 181: 735-745.

267. Colasanti M, Persichini T, Di Pucchio T, Gremo F, Lauro GM. Human ramified microglial cells produce nitric oxide upon Escherichia coli lipopolysaccharide and tumor necrosis factor alpha stimulation. Neurosci Lett 1995; 200: 144-146.

268. Dighiero P, Reux I, Hauw J, Fillet AM, Courtois Y, Goureau O. Expression of inducible nitric oxide synthase in cytomegalovirus-infected glial cells of retinas from AIDS patients. Neurosci Lett 1994; 166: 31-34.

269. Hunot S, Boissiere F, Faucheux B, Brugg B, Mouatt-Prigent A, Agid Y, et al. Nitric oxide synthase and neuronal vulnerability in Parkinson's disease. Neuroscience 1996; 72: 355-363.

270. Connop BP, Boegman RJ, Beninger RJ, Jhamandas K. Attenuation of malonate-induced degeneration of the nigrostriatal pathway by inhibitors of nitric oxide synthase. Neuropharmacology 1996; 35: $459-465$.

271. Ischirpoulos H, Duran D, Horwitz J. Peroxynitrite-mediated inhibition of DOPA synthesis in PC12 cells. I Neurochem 1995; 65: 2366-2372.

272. Paakkari I, Lindsberg P. Nitric oxide in the central ne rvous system. Ann Med 1995; 27: 369-377

273. Endoh M, Maiese K, Wagner JA. Expression of the inducible form of nitric oxide synthase by reactive astrocytes after transient global ischemia. Brain Res 1994; 651: 92-100.

274. Nowicki JP, Duval D, Poignet H, Scatton B. Nitric oxide mediates neuronal death after focal cerebral ischemia in the mouse. Eur Pharmacol 1991; 204: 339-340.

275. Bertini G, Savio T, Zaccheo D, Schmidt HHHW, Bentivoglio M. NADPHdiaphorase activity in brain macrophages during postnatal development in the rat. Neuroscience 1996; 70: 287-293.

276. Wallace MN, Fredens K. Activated astrocytes of the mouse hippocampus contain high levels of NADPH-diaphorase. Neuro Report 1992; 3: $953-956$

277. Glenn JA, Jordan FL, Thomas WE. Further studies on the identification of microglia in mixed brain cell cultures. Brain Res Bull 1989; 22 1049-1052.

278. Hassan NF, Campbell DE, Rifat S, Douglas SD. Isolation and characterization of human fetal brain-derived microglia in in vitro culture. Neuroscience 1991; 41: 149-158.

279. Gebicke-Haerter PJ, Bauer J, Schobert A, Northoff H. Lipopolysaccharide-free conditions in primary astrocyte cultures allow grow th and isolation of microglial cells. J Neurosci 1989; 9: 183-194.

280. Thiele DL, Kurosaka M, Lipsky PE. Phenotype of the accessory cell necessary for mitogen-stimulated $\mathrm{T}$ and $\mathrm{B}$ cell responses in human peripheral blood: delineation by its sensitivity to the lysosomotropic agent, L-leucine methyl ester. J Im munol 1983; 131: 2282-2290.

281. McCarthy KD, Vellis de H. Preparation of separate astroglial and oligodendroglial cell cultures from rat cerebral tissue. J Cell Biol 1980; 85: $890-902$.

282. Schwartz JP, Wilson DJ. Preparation and characterization of type 1 astrocytes cultured from adult rat cortex, cerebellum and striatum. GLIA 1992; 5: 75-80.

283. Frei K, Lins H, Schwerdel C, Fontana A. Antigen presentation in the central nervous system: the inhibitory effect of IL-10 on MHC Class II expression and production of cytokines depends on the inducing signals and the type of cell analyzed. J Im munol 1994; 152: $2720-2728$.

284. Giulian D, Baker TJ. Characterization of ameboid microglia isolated from developing mammalian brain. J Neurosci 1986; 6: 2163-2178.

285. Suzumura A, Mezitis SGE, Gonatas NK, Silberberg DH. MHC antigen expression on bulk isolated macrophage-microglia from newborn mouse brain: induction of la antigen expression by gamma-interferon.J Neuroim unol 1987; 15: 263-278.

286. Jordan FL, Thomas WE. Identification of microglia in primary cultures of mixed cerebral cortical cells. Bra in Res Bull 1987; 19: 153-159.

287. Sutter A, Gerdes C, Jarling F. Microglial contaminants as the source of IL1 in astrocyte cultures. Abstract First European Meeting on Glial Cell Function in Health and Disease, Heidelberg 1994, March 24-27, p. 174.

288. Kim YS, Tauber MG. Neurotoxicity of glia activated by gram-positive bacterial products depends on nitric oxide production. Infect Im mun 1996; 64: 3148-3153.

289. Demerle-Pallardy C, Lonchampt M, Chabrier P. Nitric oxide synthase induction in glial cells: effect on neuronal survival. Life Sci 1993; 52 $1883-1890$

290. Zielasek J, Tausch M, Toyka KV, Hartung H. Production of nitrite by 
neonatal rat microglial cells/brain macrophages. Cell Im m unol 1992; 141: $111-120$.

291. Corradin SB, Mauel J, Donini SD, Quattrocchi E, Ricciardi-Castagnoli P. Inducible nitric oxide synthase activity of cloned murine microglial cells. GLIA 1993; 7: 255-262.

292. Zhang X, Morisson DC. Lipopolysaccharide-induced selective priming effects on tumor necrosis factor $\alpha$ and nitric oxide production in mouse peritoneal macrophages. J Exp Med 1993; 177: 511-516.

293. Simmons ML, Murphy S. Induction of nitric oxide in glial cells. $J$ Neurochem 1992; 59: 897-905.

294. Hewett SJ, Corbett JA, McDaniel ML, Choi DW. Interferon- $\gamma$ and interleukin-1 $\beta$ induce nitric oxide formation from primary mouse astrocytes. Neurosci Lett 1993; 164: 229-232.

295. Gale a E, Re is DJ, Fox ES, Xu H, Feinste in DL. CD14 mediates endotox in induction of nitric oxide synthase in cultured brain glial cells. $J$ Neuroimm unol 1996; 64: 19-28.

296. Simmons ML, Murphy S. Roles for protein kinases in the induction of nitric oxide synthase in astrocytes. GLIA 1994; 11: 227-234.

297. Lee SH, Liu W, Brosnan CF, Dickson DW. Characterization of primary human fetal dissociated central nervous system with an emphasis on microglia. Lab Invest 1992; 67: 465-476

298. Goureau O, Lepoivre M, Courtois Y. Lipopolysaccharide and cytokines induce a macrophage-type of nitric oxide synthase in bovine retinal pigmented epithelial cells. Biochem Biophys Res Commun 1992; 186 : $854-859$.

299. Peterson PK, Hu S, Anderson WR, Chao CC. Nitric oxide production and neurotoxicity mediated by activated microglia from human versus mouse brain. J Infect Dis 1994; 170: 457-460.

300. Ruuls SR, Van der Linden S, Sontrop K, Huitinga I, Dijkstra CD. Aggravation of experimental allergic encephalomyelitis by administration of nitric ox ide synthase inhibitors. Clin Exp Im munol 1996; 103: $467-476$.

301. Ii M, Sunamoto M, Ohnishi K, IchimoriY. $\beta$-amyloid protein-dependent nitric oxide production from microglial cells and neurotoxicity. Brain Res 1996; 720: 93-100.

302. Goodw in JL, Uemura E, Cunnick JE. Microglial release of nitric ox ide by the synergistic action of $\beta$-amyloid and IFN-gamma. Brain Res 1995 692: 207-214.

303. Dawson TM, Dawson VL, Snyder SH. A novel neuronal messenge molecule in brain: the free radical, nitric oxide. Ann Neurol 1992; 32 297-311.

304. Skaper SD, Facci L, Leon A. Inflammatory mediator stimulation of astrocytes and meningeal fibroblasts induces neuronal degeneration via the nitridergic pathway. J Neurochem 1995; 64: 266-276.

305. Chao CC, Molitor TW, Hu S. Neuroprotective role of IL 4 against activated microglia. J Im m unol 1993; 151: 1473-1481.

306. Lipton SA. Requirement for macrophages in ne uronal injury induced by HIV envelope protein gp 120. Neuro Report 1992; 3: 913-915.

307. Bronste in DM, Perez-Otano I, Sun V, Mullis Saw in SB, Chan J, Wu GC, et al. Glia-dependent neurotoxicity and neuroprotection in mesencephalic cultures. Brain Res 1995; 704: 112-116.

308. Gelbard HA, Nottet HSLM, Swindells S, Jett M, Dzenko KA, Genis P, et al. Platelet-activating factor: a candidate human immunodeficiency virus type 1 -induced neurotoxin. J Virol 1994; 68: $4628-4635$.

309. Misko TP, Moore WM, Kasten TP, Nickols GA, Corbett JA, Tilton RG, et al. Selective inhibition of the inducible nitric oxide synthase by aminoguanidine. Eur J Pharm acol 1993; 233: 119-125.

310. Cross AH, Misko TP, Lin RF, Hickey WF, Trotter JL, Tilton RG. Aminoguanidine, an inhibitor of inducible nitric oxide synthase ameliorates experimental allergic encephalomyelitis in SJL mice. J Clin Invest 1994; 93: 2684-2690.

311. Romanic AM, Madri JA. Extracellular matrix-degrading proteinases in the nervous system. Brain Pathol 1994; 4: 145-156.

312. Southan GJ, Szabo C. Selective pharmacological inhibition of distinct nitric oxide synthase isoforms. Biochem Pharmacol 1997; 51: 383-394.

313. Park SK, Lin HL, Murphy S. Nitric oxide limits transcriptional induction of nitric oxide synthase in glial cells. Biochem Biophys Res Commun 1994; 201: 762-768.

314. Assreuy J, Cunha FQ, Liew FY, Moncada S. Feedback inhibition of nitric oxide synthase activity by nitric oxide. Br J Pharmacol 1993; 108 833-837.

315. Feinstein DL, Galea E, Reis DJ. Norepinephrine suppresses inducible nitric oxide synthase activity in rat astroglial cultures. $J$ Neurochem 1993; 60: 1945-1948.

316. Minghetti L, Nicolini A, Polazzi E, Creminon C, Maclouf J, Levi G. Inducible nitric oxide synthase expression in activated rat microglial cultures is downregulated by exogenous prostaglandin E2 and by cyclooxygenase inhibitors. GLIA 1997; 19: 152-160.

317. Hu S, Sheng WS, Peterson PK, Chao CC. Differential regulation by cytokines of production of nitric oxide by human astrocytes. GLIA 1995; 15: 491-494.

318. Park SK, Grzybicki E, Lin HL, Murphy S. Modulation of inducible nitric oxide synthase expression in astroglial cells. Neuropharmacology 1994; 33: 1419-1423.

319. Perretti M, Szabo C, Thiermermann C. Effect of interleukin-4 and interleukin-10 on leucocyte migration and nitric oxide production in the mouse. Br J Pharmacol 1995; 116: 2251-2257.

320. Liew FY, Ii Y, Severn A, Millott S, Schmidt J, Salter M, et al. A possible novel pathway of regulation by murine $T$ helper type-2 (Th2) cells of a Th1 cell activity via the modulation of the induction of nitric oxide synthase on macrophages. J Immunol 1991; 21: 2489-2494.

321. Young MRI, Farietta T, Crayton JW. Production of nitric oxide and transforming grow th factor $\beta$ in developing and adult rat brain. Mech Ageing Dev 1995; 79: 115-126.

322. Finch CE, Laping NJ, Morgan TE, Nichols NR, Pasinetti GM. TGF-beta 1 is an organizer of responses to neurodegeneration. $J$ Cell Biochem 1993; 53: 14-22.

323. Kiefer R, Stre it WJ, Toyka KV, Kreutzberg GW, Hartung H. Transforming grow th factor $\beta 1$ : a lesion-associated cytokine of the nervous system. Int J Dev Neurosci 1995; 13: 331-339.

324. Wahl SM, Allen JB, McCartney-Francis N, Morganti-Kossmann MC Kossmann T, Ellingsworth L, et al. Macrophage-and astrocyte-derived transforming grow th factor $\beta$ as a mediator of central nervous system dysfunction in acquired immune deficiency syndrome. J Exp Med 1991; 173: 981-991.

325. Pasinetti GM, Nichols NR, Tocco G, Morgan T, Laping N, Finch CE. Transforming grow th factor $\beta 1$ and fibronectin messenger RNA in rat brain: responses to injury and cell-type localization. Neuroscience 1993; 54: 893-907.

326. Peress NS, Perillo E, Seidman RJ. Glial transforming grow th factor (TGF) $\beta$ isotypes in multiple sclerosis: differential glial expression of TGF- $\beta 1,2$ and 3 isotypes in multiple sclerosis. J Neuroim munol 1996; 71: 115-123.

327. Flanders KC, Lippa CF, Smith TW, Pollen DA, Sporn MB. Altered expression of transforming growth factor $\beta$ in Alzheimer's disease. Neurology 1995; 45: 1561-1569.

328. Peress NS, Perillo E. Differential expression of TGF-beta 1,2 and 3 isotypes in Alzheimer's disease: a comparative immunohistochemical study with cerebral infarction, aged human and mouse control brains. J Neuropathol Exp Neurol 1995; 54: 802-811.

329. Samuels V, Barrett JM, Bockman S, Pantazis CG, Allen MB Jr. Immunocytochemical study of transforming grow th factor expression in benign and malignant gliomas. Am J Pathol 1989; 134: 895-902.

330. Yamada N, Kato M, Yamashita H, Nister M, Miyazono K, Heldin C, et al. Enhanced expression of transforming grow th factor- $\beta$ and its type-I and type-II receptors in human glioblastoma. Int J Cancer 1995; 62: 386-392.

331. Cheifetz S, Hernandez H, Leiho M, ten Dijke P, Iw ata KK, Massague J. Distinct transforming grow th factor- $\beta$ (TGF $\beta$ ) receptor subsets as determinants of cellular responsiveness to three TGF- $\beta$ isoforms. J Bio Chem 1990; 265: 20533-20538.

332. Chao CC, Hu S, Sheng WS, Peterson PK. Tumor necrosis factor-alpha production by human fetal microglial cells: regulation by other cytokines. Dev Neurosci 1995; 17: 97-105.

333. Merrill JE, Zimmerman RP. Natural and induced cytotoxicity of oligodendrocytes by microglia is inhibitable by TGF $\beta$. GLIA 1991; 4 : 327-331.

334. Gilbert RS, Herschman HR. Transforming grow th factor beta differentially modulates the inducible nitric ox ide synthase gene in distinct cell types. Biochem Biophys Res Commun 1993; 195: 380-384.

335. Ding A, Nathan CF, Graycar J, Derynck R, Stuehr DJ, Srimal S. Macrophage deactivating factor and transforming grow th factors- $\beta 1$, $-\beta 2,-\beta 3$ inhibit induction of macrophage nitrogen oxide synthesis by IFN gamma. J Im m unol 1990; 145: 940-944.

336. Wahl SM, Hunt Da, Wakefield LM, McCartney-Francis N, Wahl LM Roberts $A B$, et al. Transforming grow th factor beta (TGF- $\beta$ ) induces monocyte chemotaxis and grow th factor production. Proc Natl Acad Sci USA 1987; 84: 5788-5792.

337. Racke MK, Dhib-Jalbut S, Cannella B, Albert PS, Raine CS, McFarlin DE Prevention and treatment of chronic relapsing experimental allergic encephalomyelitis by transforming grow th factor- $\beta 1$. J Im munol 1991 ; 146: $3012-3017$.

338. Kuruvilla AP, Shah R, Hochwald GM, Liggitt HD, Palladino MA, Thorbecke GJ. Protective effect of transforming grow th factor $\beta 1$ on experimental autoimmune diseases in mice. Proc Natl Acad Sci USA 1991; 88: 2918-2921.

339. Karpus WJ, Sw anborg RH. CD4+ suppressor cells inhibit the function of effector cells of experimental autoimmune encephalomyelitis through a mechanism involving transforming grow th factor- $\beta$. J Im m unol 1991; 146: 1163-1168.

340. Johns LD, Sriram S. Experimental allergic encephalomyelitis: neutralizing antibody to TGF $\beta 1$ enhances the clinical severity of the disease. J Neuro imm unol 1993; 47: 1-8.

341. Santambrogio L, Hochwald GM, Saxena B, Leu C, Martz JE, Carlino JA et al. Studies on the mechanisms by which tranforming grow th factor- $\beta$ (TGF $\beta$ ) protects against allergic encephalomyelitis. J Im m unol 1993; 151: 1116-1127.

342. Rimaniol A, Lekieffre S, Serrano A, Masson A, Benavides J, Zavala F. Biphasic transforming growth factor- $\beta$ production flanking the proinflammatory cytokine response in cerebral response in cerebral trauma. NeuroReport 1995; 7: 133-136. 
343. Issazadeh S, Mustafa M, Ljungdahl A, Hojeberg B, Dagerlind A, Elde R, et $a l$. Interferon gamma, interleukin 4 and transforming grow th factor $\beta$ in ex perimental autoimmune encephalomyelitis in Lew is rats: dynamics of cellular mRNA expression in the central nervous system and lymphoid cells. I Neurosci Res 1995; 40: 579-590.

344. Mc Neill H, Williams C, Guan J, Dragunow M, Law lor P, Sirimanne E, et al. Neuronal rescue with transforming growth factor-beta 1 after hypoxic-ischaemic brain injury. Neuro Report 1994; 5: 901-904.

345. Lindholm D, Castren E, Kiefer R, Zafra F, Thoenen H. Transforming grow th factor $\beta 1$ in the rat brain: increase after injury and inhibition of astrocyte proliferation. J Cell Biol 1992; 117: 395-400.

346. Saad B, Constam DB, Ortmann R, Moos M, Fontana A, Schachner M. Astrocyte-derived TGF- $\beta 2$ and NGF differentially regulate neuronal recognition molecule expression by cultured astrocytes. J Cell Biol 1991; 115: 473-484

347. Behzadian MA, Wang X, Jiang B, Caldwell RB. Angiostatic role of astrocytes: suppression of vascular endothelial cell grow th by TGF- $\beta$ and other inhibitory factor(s). GLIA $1995 ; 15: 480-490$.

348. Chao CC, Hu S, Sheng WS, Tsang M, Peterson PK. Tumor necrosis factoralpha mediated the release of bioactive transforming grow th factor-beta in murine microglial cell cultures. Clin Im munol Im munopathol 1995; 77: $358-365$.

349. da Cunha A, Jefferson JA, Jackson RW, Vitkovic L. Glial cell-specific mechanism of TGF- $\beta 1$ induction by IL-1 in cerebral cortex. J Neuroim unol 1993; 42: 71-86.

350. McCartney-Francis N, Mizel D, Wong H, Wahl LM, Wahl SM. TGF- $\beta$ regulates production of grow th factors and TGF $\beta$ by human peripheral blood monocytes. Growth Factors 1990; 4: 27-35.

351. Yee JA, Yan L, Dominguez JC, Allan EH, Martin TJ. Plasminogendependent activation of latent transforming grow th factor beta (TGF $\beta$ ) by growing cultures of osteoblast-like cells. J Cell Physiol 1993; 157: $528-534$

352. Miyazono K, Yuki K, Takaku F, Wernstedt C, Kanzaki T, Olofsson A, et al. Latent forms of TGF- $\beta$ : structure and biology. Ann NY Acad Sci 1990; 593: $51-58$

353. Lyons RM, Gentry LE, Purchio AF, Moses HL. Mechanism of activation of latent recombinant transforming grow th factor $\beta 1$ by plasmin. $J$ Cell Biol 1990; 110: 1361-1367.

354. Sprengers ED, Kluft C. Plasminogen activator inhibitors. Blood 1987; 69: $381-387$

355. Oates JA, Wood AJJ. Tissue plasminogen activator. New Engl J Med 1988 319: 925-931.

356. Wun T, Reich E. An inhibitor of plasminogen activation from human placenta. J Biol Chem 1987; 262: 3646-3653.

357. Verheijen JH, Chang GTG, Kluft C. Evidence for the occurrence of fast-acting inhibitor for tissue-type plasminogen activator in human plasma. Throm b Haemostas 1984; 51: 392-395.

358. Vassalli JD, Sappino A, Belin D. The plasminogen activator/plasmin system. J Clin Invest $1991 ; \mathbf{8 8}$ : 1067-1072.
359. Nakajima K, Takemoto N, Kohsaka S. Retinoic acid enhances the secretion of plasminogen from cultured rat microglia. FEBS Lett 1992; 314: $167-170$

360. Nakajima K, Tsuzaki N, Nagata K, Takemoto N, Kohsaka S. Production and secretion of plasminogen in cultured rat brain microglia. FEBS Lett 1992; 308: 179-182.

361. Nakajima K, Nagata K, Hamanoue M, Takemoto N, Kohsaka S. Microgliaderived elastase produces a low-molecular-weight plasminogen that enhances neurite outgrowth in rat neocortical explant cultures. I Neurochem 1993; 61: 2155-2163.

362. Faber-Elman A, Miskin R, Schwartz M. Components of the plasminogen activator system in astrocytes are modulated by tumor necrosis factoralpha and interleukin-1 $\beta$ through similar signal transduction pathways. J Neurochem 1995; 65: 1524-1535.

363. Kalderon N, Ahonen K, Fedoroff S. Developmental transition in plasticity properties of differentiating astrocytes: age-related biochemical profile of plasminogen activators in astroglial cultures. GLIA 1990; 3: 413-425.

364. Toshniwal PK, Firestone SL, Barlow GH, Tiku ML. Characterization of astrocyte plasminogen activator. J Neurol Sci 1987; 80: 277-287.

365. Monard D. Cell-derived proteases and protease inhibitors as regulators of neurite outgrow th. Trends Neurosci 1988; 11: 541-544.

366. Seeds NW, Williams BL, Bickford PC. Tissue plasminogen activator induction in Purkinje ne urons after cerebellar motor learning. Science 1995; 270 : 1992-1994.

367. Tsirka SE, Rogove AD, Strickland S. Neuronal cell death and tPA. Nature 1996; 384: 123-124.

368. Akenami FOT, Koskiniemi M, Farkkila M, Vaheri A. Cerebrospinal fluid plasminogen activator inhibitor-1 in patients with neurological disease. J Clin Pathol 1997; 50: 157-160.

369. Akenami FOT, Siren V, Koskiniemi M, Siimes MA, Vaheri A. Cerebrospinal fluid activity of tissue plasminogen activator in patients with neurological diseases. J Clin Pathol 1996; 49: 577-580.

370. Cuzner ML, Gveric D, Strand C, Loughlin AJ, Paemen L, Opdenakker G, et al. The expression of tissue-type plasminogen activator, matrix metalloproteases and endogenous inhibitors in the central nervous system in multiple sclerosis: comparison of stages in lesion evolution. J Neuropathol Exp Neurol 1996; 55: 1194-1204.

371. Banati RB, Graeber MB. Surveillance, intervention and cytotoxicity: is there a protective role of microglia? Dev Neurosci 1994; 16 $114-127$.

372. Berdeaux A. Nitric oxide: an ubiquitous messenger. Fundam Clin Pharmacol 1993; 7: 401-411.

\section{Received 4 June 1998; accepted 4 June 1998}




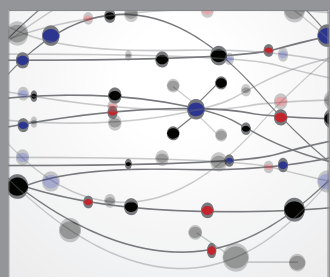

The Scientific World Journal
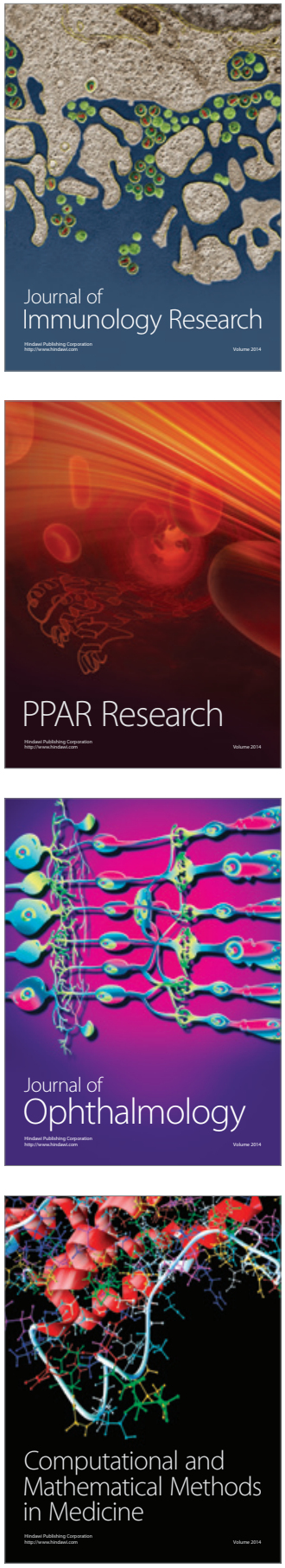

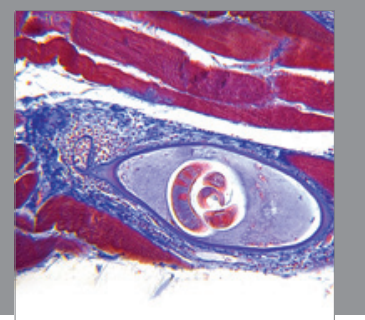

Gastroenterology

Research and Practice
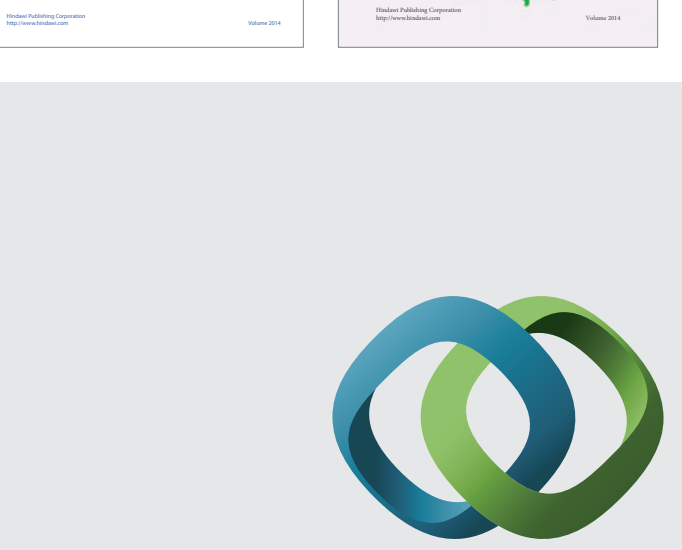

\section{Hindawi}

Submit your manuscripts at

http://www.hindawi.com
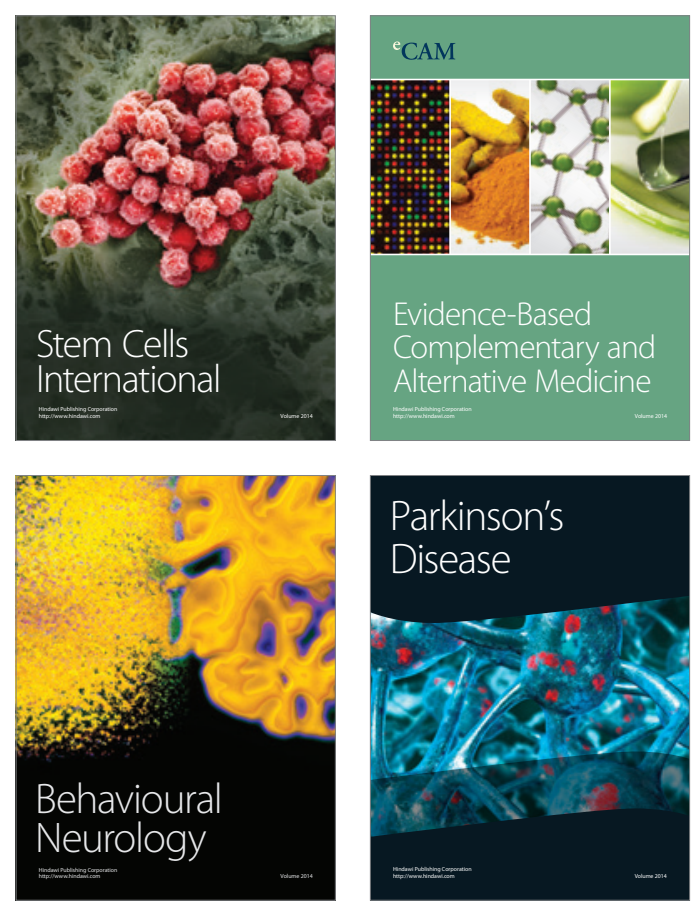

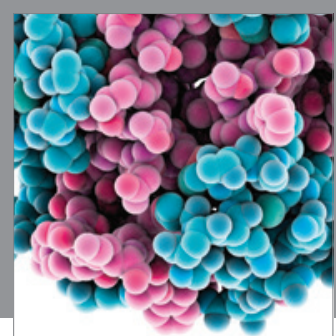

Journal of
Diabetes Research

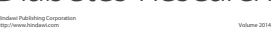

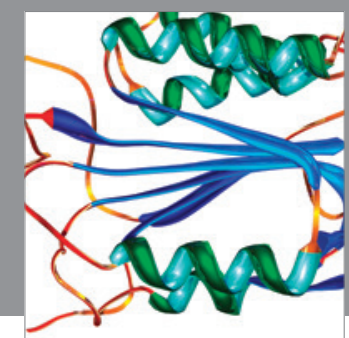

Disease Markers
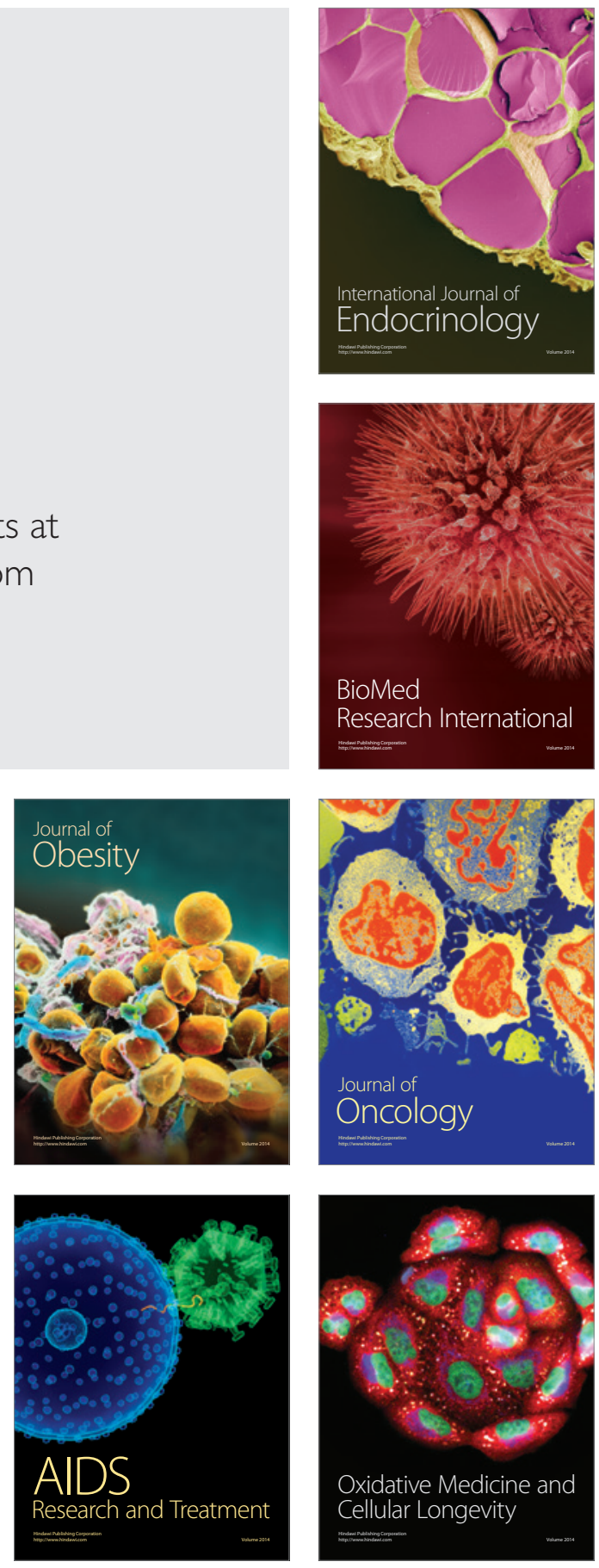